\title{
A systematic review of circular economy research in the construction industry
}

\begin{abstract}
Purpose - While Circular Economy (CE) is fast becoming a political and economic agenda for global urban development, there are still substantial knowledge gaps in possible strategies to speed up such transition, especially in the construction industry. This study analyses literature surrounding circular economy to unpack current trends possible future research directions to foster CE implementation in the construction industry.
\end{abstract}

Design/methodology/approach- The study undertakes a systematic review of Circular economy literature published between 1990 and 2019. It adopts a five-stage procedure as a methodological approach for the review: formulation of the research question(s); locating and identifying relevant studies; selection and evaluation of studies; analysis or synthesis; and results reporting.

Findings - The findings on $\mathrm{CE}$ research in the construction industry show extensive focus on resource use and waste management. There are limited investigations in other areas of construction such as supply chain integration, building designs, policy, energy efficiency, land use, offsite manufacturing, whole life costing, and risk, cost reduction, cost management, health and safety management. The study findings provide evidence that current CE practice fails to incorporate other areas that would facilitate the network of true circular construction industry.

Originality/value - This research provides a comprehensive overview of research efforts on $C E$ in the construction context, identifying areas of extensive and limited coverage over three decades. Besides, it identifies possible pathways for future research directions on CE implementation, towards the accelerated transition to a true circular construction industry for the benefit of funding bodies and researchers.

Keywords: Circular economy; construction industry; systematic review; waste management; resource reuse; sustainability 


\section{Introduction}

Circular economy (CE), which is perceived to emerge from the field of industrial ecology has recently earned the attention of practitioners, including policymakers and scholars from different field of study and industry (Preston, 2012; Geissdoerfer et al., 2017). This can be linked to the fundamental need and desire for an alternative approach to the traditional linear model of growth or linear economy of take - make - dispose of materials (Lieder and Rashid, 2016; Schroeder et al., 2019). The concept has been accepted by businesses across different sectors around the world as a solution to promote sustainability (Preston, 2012; Lieder and Rashid, 2016; Ghisellini et al., 2018) and the construction industry is not an exception.

The construction industry is said to produce more waste than any other industrial sector (Rose and Stegemann, 2018). Despite the vast amount of waste from construction activities (Clark et al., 2006; Lieu et al., 2011; Bilal et al., 2016), and significant impacts of the construction industry on the environment, society and economy (Gencel et al., 2012) limited studies have been conducted on CE application within the construction industry (Lieder and Rashid, 2016). Studies (Tukker, 2015; Pan et al., 2015) suggested the need to explore strategies to convert and/ or recover the industry waste for recycling and reuse). This idea is consistent with Smol et al. (2015), views, who argued that the construction sector could benefit maximally from CE. Other studies clamouring for sustainability in the construction industry (Lemougna et al., 2011; Kylili and Fokaides, 2017; Lai et al., 2017; Ghisellini et al., 2018) have highlighted the importance of CE in this process. These studies suggest the need to explore the efficacy of CE in the construction industry and to understand the extent to which the principles of CE are applicable in the construction activities. This may necessitate the synthesis of the current knowledge in the literature, especially regarding different research focus/domains, on the implementation of $\mathrm{CE}$ in the construction industry. Therefore, exploring viable strategies for accelerating the construction industry's transition CE should fast become the centre of current and further investigations. One such strategy is to identify the extent of research coverage on $\mathrm{CE}$ implementation in the construction industry from existing literature. Hence, this study systematically analyses literature surrounding $\mathrm{CE}$ in the construction 
industry to provide a clear understanding of the research efforts and possible pathways to foster CE implementation in the construction industry.

\section{Literature review}

\subsection{Definition of circular economy (CE)}

CE is positioned as an efficient method for resource transformation into valuable materials for other processes and products (Preston, 2012). Similarly, MacArthur (2013) referred to CE as a process aimed at maintaining products, materials and components for maximum value of time performance and utility, with the primary goal of eradicating waste. This thinking is consistent with Mitchell's (2015) assertion that CE emphasizes the efficient utilization of resources by extracting maximum value from materials and products beyond their normal useful life.

Furthermore, Kirchherr et al. (2017) defined CE as an approach to replacing the end-of-life concept with an economic system that fosters reuse, alternatively reducing, recovering, and recycling of materials in distribution/ production and consumption processes. Likewise, Geissdoerfer et al. (2017) describe CE as a regenerative process, which maximizes the utilization of raw materials, and reduces emissions and waste generation through repair, remanufacture, reuse, recycling and refurbishing. Even though CE lacks a generally acceptable definition among scholars and practitioners, there is a consensus that it promotes longer lifecycle of components, materials and products through reuse, repair, recycling, remanufacture and refurbishing (Zacho et al., 2018).

These views suggest that the concept of CE focuses on material and physical resource aspects of the economy (EEA, 2014), which could nurture a constructive path to sustainable development. Taken together, CE can be construed as a recovery system that can minimize resource consumption, waste production, energy leakage, and emission by closing, narrowing, and slowing material and energy loops (Geissdoerfer et al., 2017).

\subsection{CE in the construction industry}

Despite the economic, social and environmental contribution of the construction industry (Gencel et al., 2012), it accounts for the highest amount of total waste 
generated globally (Núñez-Cacho et al., 2018; van Dijk et al., 2014; Clark et al., 2006). While the construction industry consumes more resources than any other industry (Pomponi and Moncaster, 2017), it also accounts for over $40 \%$ of the world's carbon emission. According to Kibert (2016), over 50\% of the entire waste being generated in the construction industry is associated with end-of-life activities and operations, which are primarily from demolition. However, only about $30 \%$ of these materials are either reused or recycled (Macarthur, 2013).

The current view suggests that it is likely impossible to reuse materials within the construction industry considering that buildings are often disposed of at the end of their useful life. For example, demolition and construction waste in the UK is at an annual average of 45.8 million tons (Akanbi et al., 2018). In response to Nuñez-Cacho et al.'s (2018) observation that the construction industry requires a closer attention due to its environmental impact, the industry should improve its resource consumption (Smol et al., 2015). The current trends and practices in the construction industry suggest that $\mathrm{CE}$ can facilitate the sustainability of the industry. The starting point is to understand how CE could contribute to the construction industry, given that $C E$ can be instrumental in reducing the environmental impact of the construction activities (Ghisellini et al., 2018). This is in line with van Stijn and Gruis (2019, p.1) assertion that "the transition to a circular economy in the built environment is key to achieving a resource-effective society". As a result, this study is designed to assess the current research focus on CE in the construction industry and how the concept has been conceptualized in the academic literature.

\section{Material and methods}

To understand the focus of research on $C E$ in the construction literature, $a$ systematic review was conducted using relevant and available scholarly studies that were published between 1990 and 2019. The rationale for the year 1990 is due to its importance in popularizing the paradigm of sustainability following the publication of the Brundtland report in 1987. Although literature surrounding CE in construction is still in its infancy, the concept is sustainability from which the principles of CE derives have had its root since the 1980s. Furthermore, there was a need to align the search to the period when CE was formally used (Pearce and Turner, 1990). Similarly, a systematic review wâs adopted due to its potential in 
characterizing the extant studies to identify or argue in support of emerging trends (Jabbour, 2013; Mariano et al., 2015). As espoused by Thorley et al. (2020), this approach to the review of literature is most efficient to evaluate extensive literature towards high-quality outcomes. This approach to data collection has been successfully applied by many scholars (such as Costa and Godinho Filho, 2016; Fahimnia et al, 2015) to summarize research findings of similar themes based on predefined criteria. Denyer and Tranfield's (2009) suggested a five-stage procedure to a systematic literature review. This procedure includes the formulation of question(s); locating and identifying relevant studies; selection and evaluation of studies; analysis or synthesis; and results reporting. Denyer and Tranfield's (2009) procedure has been adopted in this research (Figure 1). This choice is underpinned on its rigour and use by previous studies (Thorley et al., 2020) to facilitate easy replication, focus on understanding specific research questions using existing studies and reporting the outcome about what is known and unknown.

\section{Insert Figure 1 here}

\subsection{Formulation of research questions}

Consistent with Figure 1, the following research questions were explored in this study:

1. How has research on CE been conceptualized? What were the main areas investigated?

2. What research method(s) have been used in CE research?

3. What is the current knowledge regarding the application of $C E$ in the construction industry?

Using Figure 1 as a basis, this study adopted the following search criteria to identify and retrieve relevant peer-reviewed studies to answer the identified research questions:

1. The article's title or subject had to do with CE in the construction industry.

2. The journal articles published between 1990 and 2019.

3. The articles were scholarly peer-reviewed journals. 
4. Only academic journal articles are considered. Hence, company reports are excluded.

5. The journal articles were published in English language. This gave room for easy review and analysis of included articles.

Articles not written in English were excluded for ease of analysis and understanding (Osobajo and Moore, 2017). Only peer-reviewed articles were considered for this systematic review to ensure that all articles have been subjected to the same analytical and review structure, minimizing bias, and foster a fair representation of articles of interest.

\subsection{Data Source}

Having designed the research question, the second stage (see Figure 1) that involves the efforts to locate and identify relevant studies was further sub-categorized into different sequential steps (Figure 2) to arrive at the selected relevant articles. The initial search was conducted through electronic databases, such as Scopus and Web of science, for all journal articles that focused on CE within the construction industry. These databases are considered appropriate because they are found to be effective in literature search, include a more expanded spectrum of journals and citation analysis, and cover most scientific fields (Falagas et al. 2008). Pelz (2019) added that Scopus is efficient because it allows search results to be directly exported into a spreadsheet. Arguably, this will be useful in organizing a large amount of initial search outcome to identify relevant literature for this study. Using this approach, only peer-reviewed journal articles that are relevant to the theme of this current study were retrieved. Based on the search criteria, a total of 50 peer-reviewed journal articles on CE were found to be relevant to the goal of this study and included for further analysis. The search for relevant peer-reviewed journal articles was conducted in the fourth quarter of 2019.

\section{Insert Figure 2 here}

The selected sources based on the inclusion criteria are presented in Table 1, although Appendix A presents detailed information about the selected peer- 
reviewed articles. Also, Appendix B present the findings of the journal article reviewed. The result and discussion section explain these findings further.

\section{Insert Table 1 here}

\section{Results and discussion}

As presented in Table 1, only fifty studies were considered relevant for further analysis. The reviewed articles were selected not solely by their quality, but was assessed based on the reliability of its findings (Denyer and Tranfield, 2009) coupled with their relevance to the current study.

\subsection{Studies overview}

Although, CE was formally used in 1990 by Pearce and Turner (1990) within the economic discipline in support of the claim that "everything is input to everything else", the concept has received little or no scrutiny within the construction industry until about 2007. During the early period of its introduction to the construction industry, an average of two peer-reviewed articles were published yearly. However, CE started gaining momentum among researchers and scholars from the year 2016, during which an average of nine peer-reviewed articles was published annually (see Figure 3). This is consistent with Pomponi and Moncaster (2017) assertion that CE is attracting interest as an emerging paradigm which may be attributed to the publication of the Brundtland report in 1987. On the contrary, early studies conducted on the construction activities concerning resource use before 2016 were underpinned by the linear economy model.

\section{Insert Figure 3 here}

\subsection{Understanding CE in CI}

To understand the extent to which the principles of CE are applicable in the CI, attempt was made to establish the background of CE definition used by journal articles. All the artilcles reviewed agreed that CI needs to be transformed from a linear economy toward a circular approach to achieve a sustainable future. However, only fourteen of the studies reviewed attempt to define CE within the construction industry context as shown in table 2 . This finding further strengthens 
the argument that $\mathrm{CE}$ is a relatively new topic that is gaining momentum within the contruction industry (Pomponi and Moncaster 2017; Leising, Quist and Bocken 2018).

\section{Insert Table 2 here}

\section{3 Study focus}

Figure 4 presents the different areas in which scholars and researchers have concentrated their effort in the last decade. About $64 \%$ of the studies reviewed had a link with building materials and resources with $34 \%$ and $30 \%$ for resources reuse and waste management, respectively. This is consistent with Su et al. (2013), who argued that scholars should advance their research activities beyond issues related to material management. Other areas that have been researched into but with a minimal attention are CE model (10\%), supply chain $(8 \%)$, building designs (6\%), policy $(6 \%)$, energy efficiency $(4 \%)$, and land use (2\%).

\section{Insert Figure 4 here}

\subsubsection{Resources reuse}

According to the findings of the review, resource reuse remains a major concern for scholars and practitioners within the construction industry. This is because resource consumption provides the built environment with a basis for outlining the emerging lifecycle issues within the industry (Fernandez, 2007). This is in line with Lemougna et al.'s (2011) assertion that an awareness of reuse will foster the attainment of a friendly environment and contribute to solving the problem of affordable housing. Exploring material performance in the construction of new buildings may promote material use and reduce $\mathrm{CO} 2$ emissions (Huang et al., 2013). These views suggest that an understanding of material reuse is essential for the improvement and success of the construction industry.

While reuse contributes to sustainability in construction (Atolagbe and Fadamiro, 2014; Sfakianaki, 2015), Akanbi et al. (2018) argued that materials components should be appraised to encourage the adoption of recoverable materials that are mostly reusable. This is because appropriate management of materials components contribute to sustainable development (de Freitas \&t al., 2018). 
Besides, reuse of resources at the end-of-life of a building will yield both economic and environmental benefits (Ghisellini et al., 2018). However, an understanding of construction material and how reuse will contribute to sustainability and CE are required (López-Uceda et al., 2018). Likewise, Minunno et al. (2018) argued the environmental advantages of material reuse should be explored in improving the CE of buildings. Arguably, having an adequate understanding and appropriate use of construction material resources can lead to improved performance as well as increasing the industry sustainability performance (Sierra-Pérez et al. 2018; Mobili et al., 2018; Corradini et al., 2019).

\subsubsection{Waste management}

The findings of this study show that construction and demolition waste is a major contributor to environmental pollution. It is, therefore, imperative to minimize and/or eliminate waste where possible and feasible in construction activities (Tam et al., 2007; Yuan et al., 2011). Waste prevention through the efficient use of construction materials will benefit the industry environmentally and economically (Smol et al. 2015). Esa et al. (2017) argued that efficient waste management within the industry could be achieved through the concept of CE. This may involve an inclusive and collaborative effort among different stakeholders within the industry (Tong and Tao, 2016).

Although efficient utilization of construction waste is salient to sustainable development (Karayannis et al., 2017; Aneke and Awuzie, 2018), poor waste management monitoring remains a major challenge for the industry according to the reviewed studies. However, it is imperative to comprehensively evaluate the contribution of waste materials at various construction stages to environmental impacts (Hossain et al., 2019).

\subsubsection{CE model}

The design and application of CE models that are specific to the construction industry are lacking in the construction literature according to our review. However, Dean et al. (2014) analyzed four independently operated ecosmart corporate communities in USA and China and proposed an expanded business operations model that can be instrumental in assessing environmental 
stewardship within the construction industry. Likewise, Nuñez-Cacho et al. (2018) designed a scale that will provide information on the degree of the long-term sustainability of the construction company and the degree of $\mathrm{CE}$ implementation. Based on the findings of this study and supported by van Breugel (2018), the industry should emphasise the application of models that may allow for sustainable solutions in the construction industry. Wuyts et al. (2019) concluded that the availability of frameworks would be useful in deciding the life expectant of building, i.e. to extended or ended.

\subsubsection{Supply chain integration}

Another important area that is attracting less attention in the construction literature within the domain of CE is supply chain management. Mohamed Abdul Ghani et al. (2017) observed that the understanding of the principles of CE within the context of sustainable development is essential in combating the emissions of greenhouse gases (GHG) across the construction supply chain. Besides, Nasir et al. (2017) argued that the integration of CE principles within sustainable supply chain management could provide clear advantages for the construction industry. Also, Leising et al. (2018) concluded that developing circular buildings requires a new process design where a variety of disciplines in the supply chain is integrated upfront. The lack of interest in the supply chain as revealed by this systematic review serves as a pointer for scholars to explore this area in more depth in understanding how the construction industry can embed CE across its supply chains.

\subsubsection{Other focus areas}

Another important area of interest is adaptive reuse which can contribute to CE in the construction industry. According to Sanchez et al. (2019), adaptive reuse of building structures produce a considerable decrease in the environmental impacts and the construction building cost. Besides, studies (such as Almirall et al. 2019; Lai et al. 2017) argued for more focus on policies and regulations in the sustainability of construction assets.

Considering the issues of climate change, studies should focus on identifying relevant driving forces of low carbon technology innovation and their interaction 
in the construction industry. Also, Hong et al. (2014) explored the re-adjustment and optimization of land use patterns and came to a conclusion that pursuing sustainable development and building an ecological civilization is imperative for the future of the construction industry.

While it is evident from the studies reviewed, that researchers continue to strive toward advancing CE within the construction industry, WRAP (2013) asserted that best practice guidance such as offsite construction, design for deconstruction, sustainable procurement, IBM and design out waste should be addressed to promote CE. The concept of circularity is considered to be an instrument for mitigating the environmental footprint of the construction industry (van Breugel, 2018).

\subsection{Data collection tool}

As shown in figure 5 , of the 50 peer-reviewed journal articles identified for the current study, 16 articles (32\%) make use of solely secondary data that are readily available from the other sources, while $68 \%$ of the articles reviewed used primary data. According to this review, the prominent data collection methods include case study, experiment, interview, questionnaire, field visit, workshop and observation are the different sources of primary methods of data collection used. Twelve articles (24\%) employed case study, eight articles $(16 \%)$ utilized experiment, three articles (6\%) utilized interview, two articles (4\%) used questionnaire, one article (2\%) utilized workshop, one article (2\%) utilized observation, and another seven articles (14\%) employed more than one method of data collection. Furthermore, 2 articles (4\%) of the journal articles reviewed utilised a mixed-method approach. In summary, 92\% (46 articles) of the articles reviewed employed qualitative method while little attention has been accorded to quantitative (2 articles (4\%)) and mixedmethod (2 articles (4\%)).

In spite of Pelz (2019) argument that qualitative studies could help to sharpen current theoretical understanding and point to new ones, not enough information about the validity and reliability of the qualitative instruments employed were provided by studies reviewed. Also, considering the different understanding of $\mathrm{CE}$ in the construction industry, there is clearly a need for further research on $\mathrm{CE}$ from 
a quantitative and mixed-method perspective. Such a perspective may allow for more objective measures with an opportunity to generalize the research findings.

\section{Insert Figure 5 here}

\subsection{Type of study}

As shown in figure 6 , thirty-five (70\%) of the articles analyzed are classified as empirical studies, while fifteen (30\%) of the journal articles are classified as theoretical studies, which establishes what theories already exist, and to develop new hypotheses to be tested.

\section{Insert Figure 6 here}

Sample size and characteristics were assessed to determine if any pattern existed among the reviewed articles and the extent to which these are generalizable. It was observed that empirical studies that focused on material reuse included researchers, architects, consultants and other construction practitioners as the study participants. Also, building types and building materials are used as a case study. Likewise, studies that focused on waste management considered construction experts and various construction stakeholders for their sample study. Also, different construction and building materials are used as a case study. Furthermore, studies that focused on models considered eco-smart buildings as case study. Studies that focused on supply chain considered different building types and construction materials in their study. Studies that focused on Building designs considered public sector clients, value managers and VM facilitators as sample. Studies that focused on policy considered building material as case study. It was clear from the studies reviewed that building types and building materials remain a key focus for many researchers.

\subsection{Study context}

All peer-reviewed journal articles $(N=50)$ selected for this study were conducted in one of 23 different countries. 24 studies (48\%) were conducted in developed countries, while 20 studies (40\%) were conducted in developing countries, as shown in Figure 7. Only 6 of the studies (12\%) reviewed considered both developed and developing countries. Of the studiథs conducted in developed 
countries, the United Kingdom was the dominant country that attracted the attention of scholars, while studies on China was dominant among developing countries. Arguably, studies on circular economy within the construction industry has caught both the attention of scholars in both developed and developing countries. However, lesser attention has been given to comparative studies (i.e. studies involving both developed and developing countries).

\section{Insert Figure 7 here}

\subsection{Study Continent}

Figure 8 revealed that the peer-reviewed journal articles considered for this study had been carried out in 6 different continents. However, Europe and Asia with 20 studies (40\%) and 17 studies (34\%) respectively dominated the review. Only 3 studies, 2 studies, 1 study and I 1study were conducted in Africa, North America, South America and Australia respectively. Furthermore, 4 studies and 1 study were conducted in 2 continents and 3 continents, respectively. These findings suggested that the circular economy has received more attention from scholars within Europe and Asia. Hence, more research activities are required in other continents such as Africa, North America, South America and Australia. Also, researchers should look into studies that will cut across two or more continents. This will allow and support cross-cultural awareness across continents.

\section{Insert Figure 8 here}

\section{Gaps in the literature and Future Research Agenda}

The review showed different research focus as well as the application of CE in the construction industry. However, the key findings from the reviewed papers (Figure 9) suggest the gaps in the literature and allow for the identification of the direction for future research on CE within the construction industry. For sustainability to be achieved within the construction industry through the CE principles, it is intuitive for research efforts to address and further explore the utility of the CE framework, as presented in Figure 9. The knowledge would allow for the design of new innovative process models and also provide an opportunity for the construction industry to integrate the identified dimensions into its current activities. 


\section{Insert Figure 9 here}

\subsection{Offsite construction}

Apart from Elmualim et al. (2018) study on how smart and industrialised prefabrication can be used for $C E$, there is no other research on the construction industry on how CE can influence offsite manufacturing. Offsite manufacturing in the construction industry span from simple precast beams and columns to prefabricated walls and building elements before modular houses. Arguably, researchers should investigate further the application of circularity in the offsite manufacturing process. The investigation could focus on the plausibility of material and resource reuse during design and deconstruction. Furthermore, research and models must be designed to harness limited material and financial resources in offsite construction through CE.

\subsection{Cost reduction and management}

Studies (such as Omotayo and Kulatunga, 2015; Omotayo et al., 2019; Arif et al., 2015) have discussed the cost management concept in the domain of construction waste reduction. The peculiarity of cost reduction is evident and more practical in offsite construction. For instance, Kaizen costing, lean construction and other forms of cost management techniques can be used in the construction industry, especially in offsite construction, to reduce waste. Although construction waste can be tangible and intangible, the principles of CE may increase material reuse in the construction process, which may feed into effective cost models to achieve cost reduction. According to the findings of this study, cost modelling through material reuse and activity feedback loops using kaizen costing may be a potential research area in the field of construction management. This study further argues that any attempts to enhance the productivity of construction activities through CE should consider the propensity for construction cost reduction through many approaches, such as value management systems and value engineering, that could be integrated into CE models in the construction industry.

\subsection{Whole life cycle costing}


To achieve circularity in the construction industry, the whole life cycle costing is another approach that can be adopted and integrated into CE models. According to Albuquerque et al. (2019), the rationale is to address the issues of sustainability that are associated with business operations by integrating externalities into life cycle costing models. This assertion is supported by Harts et al. (2019) who identified whole life cycle costing as an enabler for the implementation of a CE in the built environment. Also, Chen and Huang (2019) observed that the application of life cycle assessment is of significant importance to circular economy for products services.

Since whole life cycle costing adopts costing from social, environment and governance perspectives, its contribution in reducing construction cost cannot be underestimated. Although circularity is still emerging in the construction industry, whole life cycle costing is an essential approach that can be implemented and integrated to achieve circularity. Therefore, research into the application of whole life cycle, costing in achieving a circular economy will provide a more in-depth insight into how construction costs can be reduced or maintained throughout a built asset. While Albuquerque et al. (2019) studied whole life cycle costing and $\mathrm{CE}$ in the food and beverages industry, we proposed that future research in the construction industry should assess the utility of whole life cycle costing when designing circular economy models for the construction operations.

\subsection{Risk, health and safety management}

Another potential area for future CE research in the construction industry is issues of risk, health and safety management considering the number fatalities in the industry. This research area is necessary considering that risk, health and safety issues have not been sufficiently addressed, especially in the CE literature. Hence, the need for the construction industry to be more effective in evaluating and managing different uncertainties confronting its operations, particularly to achieve sustainability and in creating sustainable values for stakeholders/shareholders is on the increase. For instance, future research should consider the possibility of preparing risk registers in CE when assessing health and safety-related issues in construction projects. Also, material consumption (such as reuse or recycling) mitigating measures should focus on CE by incorporating risk, health and safety 
identification approaches, particularly during the construction and prefabrication processes.

\section{Conclusion and recommendation}

In this paper, we extend the present understanding of CE studies reported in the construction industry based on peer-reviewed journal articles published between 1990 and 2019 through a systematic literature review. In total 50 articles were included in the review.

According to the findings of the study, extensive studies on CE in the construction industry have focused on resource use and waste management. It is clear from the research in $\mathrm{CE}$ in the construction industry that research focuses on CE impacts in areas of supply chain integration, building designs, policy, energy efficiency, land use, offsite manufacturing, cost reduction and cost management, whole life costing, and risk, health and safety is limited. These are key areas influencing construction decisions and activities to foster a rapid transition to $\mathrm{CE}$ in the construction industry hence possible areas for further research. There must be more research into policy interventions to support CE transition in the construction industry. Research on CE impact on offsite manufacturing, whole life cycle costing and building designs will influence sustainable strategic decisions to support resource use and waste reduction. There must be research identifying influences of supply chain integration and risk management frameworks to enable supply chain organisations to reevaluate their processes and towards accelerated transition into CE practices. Research on cost optimization and health and safety within the CE context in terms of the productivity and investment benefits will enable guidance necessary for a paradigm shift from conventional business models. Focusing on these areas will play a significant role in moving the construction industry further towards creating a novel sustainable future.

Also, the findings showed the dominance of the qualitative research approach in existing CE research. This suggests that future research should endeavour to adopt quantitative method or mixed-method to provide a more objective stance regarding the utility of CE in the industry. Using either of these methods will create more avenues that can facilitate the implementation and application of CE models that are specific to the construction industry. In addition, there is 18 fair balance in 
the studies conducted in both developed and developing countries, although this discovery is not unexpected, given the fact that $\mathrm{CE}$ can be instrumental in promoting the sustainability agenda. However, it is observed that comparative studies, using different countries and/or construction activities as a unit of analysis, have not been appropriately considered. One possible future research agenda could involve two or more countries, especially from developing and developed countries and across different continents.

While this study identified different studies on CE in the construction industry, the selection parameters that restricted the retrieved studies to only published peer-reviewed articles are considered as the main limitation of this study. Future study may consider published books, conference papers and grey articles that may provide further insights into the application of CE in the construction industry.

Funding: This research did not receive any specific grant from funding agencies in the public, commercial, or not-for-profit sectors. 


\section{References}

Akanbi, L.A., Oyedele, L.O., Akinade, O.O., Ajayi, A.O., Delgado, M.D., Bilal, M. and Bello, S.A. (2018), "Salvaging building materials in a circular economy: A BIM-based whole-life performance estimator", Resources, Conservation and Recycling, Vol. 129, pp.175-186. https://doi.org/10.1016/j.resconrec.2017.10.026

Albuquerque, T.L., Mattos, C.A., Scur, G. and Kissimoto, K. (2019), "Life cycle costing and externalities to analyze Circular Economy Strategy: Comparison between aluminum packaging and tinplate". Journal of Cleaner Production, Vol. 234, pp.477-486. https://doi.org/10.1016/j.jclepro.2019.06.091

Almirall, C., Petit-Boix, A., Sanjuan-Delmás, D., De la Fuente, A., Pujadas, P. and Josa, A. (2019), "Environmental effects of using different construction codes applied to reinforced concrete beam designs based on Model Code 2010 and Spanish Standard EHE-08", Engineering structures, Vol. 179, pp.438-447. https://doi.org/10.1016/j.engstruct.2018.11.013

Aneke, F.I. and Awuzie, B. (2018), "Conversion of industrial wastes into marginal construction materials", Acta Structilia, Vol. 25 No. 2, pp.119-137. https://doi.org/10.18820/8820/24150487/as25i2.5

Obi, L. Arif, M., and Awuzie, B. (2015), "Significant waste factors influencing delivery cost performance of design and build low-cost housing projects in Imo State Nigeria", Journal of Construction Project management and Innovation, Vol. 5 No. 2, pp.1152-1175.

Atolagbe, A.M.O. and Fadamiro, J.A. (2014), "Indigenous African building techniques and the prospects for sustainable housing and environmental development", Environment, development and sustainability, Vol. 16 No. 5, pp.1041-1051. https://doi.org/10.1007/s10668-013-9510-9

Bilal, M., Oyedele, L.O., Akinade, O.O., Ajayi, S.O., Alaka, H.A., Owolabi, H.A., Qadir, J., Pasha, M. and Bello, S.A. (2016), "Big data architecture for construction waste analytics (CWA): A conceptual framework", Journal of Building Engineering, Vol. 6, pp.144-156. https://doi.org/10.1016/j.jobe.2016.03.002 
Chang, R.D., Soebarto, V., Zhao, Z.Y. and Zillante, G. (2016), "Facilitating the transition to sustainable construction: China's policies", Journal of Cleaner Production, Vol. 131, pp.534-544. https://doi.org/10.1016/j.jclepro.2016.04.147

Chiang, K.Y., Yen, H.R. and Lu, C.H. (2019), "Recycled gypsum board acted as a mineral swelling agent for improving thermal conductivity characteristics in manufacturing of green lightweight building brick", Environmental Science and Pollution Research, Vol. 26 No. 33, pp.34205-34219. https://doi.org/10.1007/s11356-018-3801-5

Clark, C., Jambeck, J. and Townsend, T. (2006), "A review of construction and demolition debris regulations in the United States", Critical Reviews in Environmental Science and Technology, Vol. 36 No. 2, pp.141-186. https://doi.org/10.1080/10643380500531197

Corradini, G., Pierobon, F. and Zanetti, M. (2019), "Product environmental footprint of a cross-laminated timber system: a case study in Italy", The International Journal of Life Cycle Assessment, Vol. 24 No 5, pp.975-988. https://doi.org/10.1007/s11367-018-1541-x

Costa, L.B.M. and Godinho Filho, M. (2016), "Lean healthcare: review, classification and analysis of literature. Production Planning \& Control, Vol. 27 No. 10, pp.823-836. https://doi.org/10.1080/09537287.2016.1143131

de Freitas, S.M.A.C., Sousa, L.N., Diniz, P., Martins, M.E. and Assis, P.S. (2018), "Steel slag and iron ore tailings to produce solid brick", Clean Technologies and Environmental Policy, Vol. 20 No 5, pp.1087-1095. https://doi.org/10.1007/s10098-018-1513-7

Dean, C.A., Fath, B.D. and Chen, B. (2014), "Indicators for an expanded business operations model to evaluate eco-smart corporate communities", Ecological indicators, Vol. 47, pp.137-148. https://doi.org/10.1016/j.ecolind.2014.07.010

Denyer, D., and Tranfield, D. (2009), "Producing a systematic review. In D. A. Buchanan \& A. Bryman (Eds.)", The Sage handbook of organizational research methods, Sage Publications Ltd, London, pp.671-689. https://psycnet.apa.org/record/2010-00924-039 
EEA (European Environment Agency) (2014), "Resource-efficient Green Economy and EU policies", Luxembourg: Publications Office of the European Union. Available at: https://www.eea.europa.eu/publications/resourceefficient-greeneconomy-and-eu (accessed 22 November 2019).

Elmualim, A., Mostafa, S., Chileshe, N. and Rameezdeen, R. (2018), "Construction and the Circular Economy: Smart and Industrialised Prefabrication", Unmaking Waste in Production and Consumption: Towards the Circular Economy, Emerald Publishing Limited, pp.323-336. https://doi.org/10.1108/978-1-78714-619$\underline{820181025}$

Esa, M.R., Halog, A. and Rigamonti, L. (2017), "Developing strategies for managing construction and demolition wastes in Malaysia based on the concept of circular economy", Journal of Material Cycles and Waste Management, Vol. 19 Nos 3, pp.1144-1154. https://doi.org/10.1007/s10163-016-0516-x

Fahimnia, B., Tang, C.S., Davarzani, H. and Sarkis, J. (2015), "Quantitative models for managing supply chain risks: A review", European Journal of Operational Research, Vol. 247 No. 1, pp.1-15. https://doi.org/10.1016/j.ejor.2015.04.034

Falagas, M.E., Pitsouni, E.I., Malietzis, G.A. and Pappas, G. (2008), "Comparison of Pubmed, Scopus, Web of Science, and Google Scholar: strengths and weaknesses", FASEB Journal, Vol. 22, pp. 338-342. https://doi.org/10.1096/fj.07-9492LSF

Fernandez, J.E. (2007), "Resource consumption of new urban construction in China", Journal of Industrial Ecology, Vol. 11 Nos 2, pp.99-115. https://doi.org/10.1162/jie.2007.1199

Geissdoerfer, M., Savaget, P., Bocken, N.M. and Hultink, E.J. (2017), "The Circular Economy-A new sustainability paradigm?", Journal of cleaner production, Vol 143, pp.757-768. https://doi.org/10.1016/j.jclepro.2016.12.048

Geldermans, R.J. (2016), "Design for change and circularity-accommodating circular material \& product flows in construction", Energy procedia, Vol. 96, pp.301-311. https://doi.org/10.1016/j.egypro.2016.09.153 
Gencel, O., Ozel, C., Koksal, F., Erdogmus, E., Martínez-Barrera, G. and Brostow, W. (2012), "Properties of concrete paving blocks made with waste marble", Journal of Cleaner Production, Vol. 21 No. 1, pp.62-70. https://doi.org/10.1016/j.jclepro.2011.08.023

Ghisellini, P., Ripa, M. and Ulgiati, S. (2018), "Exploring environmental and economic costs and benefits of a circular economy approach to the construction and demolition sector. A literature review", Journal of Cleaner Production, Vol. 178, pp.618-643. https://doi.org/10.1016/j.jclepro.2017.11.207

Hart, J., Adams, K., Giesekam, J., Tingley, D.D. and Pomponi, F. (2019), "Barriers and drivers in a circular economy: the case of the built environment", Procedia CIRP, Vol. 80, pp.619-624. https://doi.org/10.1016/j.procir.2018.12.015

He, B.J., Yang, L., Griffy-Brown, C., Mou, B., Zhou, Y.N. and Ye, M. (2014), "The assessment of building energy efficiency in China rural society: Developing a new theoretical construct", Technology in Society, Vol. 38, pp.130-138. https://doi.org/10.1016/j.techsoc.2014.04.002

Hong, W., Li, F., Li, M., Zhang, F., Tong, L. and Huang, Q. (2014), "Toward a sustainable utilization of land resources in China: problems, policies, and practices" Ambio, Vol. 43 No. 6, pp.825-835. https://doi.org/10.1007/s13280$\underline{013-0464-9}$

Hossain, M.U., Sohail, A. and Ng, S.T. (2019), "Developing a GHG-based methodological approach to support the sourcing of sustainable construction materials and products", Resources, Conservation and Recycling, Vol. 145, pp.160-169. https://doi.org/10.1016/j.resconrec.2019.02.030

Huang, B., Wang, X., Kua, H., Geng, Y., Bleischwitz, R. and Ren, J. (2018), "Construction and demolition waste management in China through the $3 R$ principle", Resources, Conservation and Recycling, Vol. 129, pp.36-44. http://dx.doi.org/10.1016/j.resconrec.2017.09.029

Huang, T., Shi, F., Tanikawa, H., Fei, J. and Han, J. (2013), "Materials demand and environmental impact of buildings construction and demolition in China based 
on dynamic material flow analysis", Resources, Conservation and Recycling, Vol. 72, pp.91-101. https://doi.org/10.1016/j.resconrec.2012.12.013

Jabbour, C.J.C. (2013), "Environmental training in organisations: From a literature review to a framework for future research", Resources, Conservation and Recycling, Vol. 74, pp.144-155. https://doi.org/10.1016/j.resconrec.2012.12.017

Jiménez-Rivero, A., Guzmán-Báez, D. and García-Navarro, J. (2017), "Enhanced on-site waste management of plasterboard in construction works: A case study in Spain", Sustainability, Vol. 9 No. 3, p.450. https://doi.org/10.3390/su9030450

Karayannis, V.G., Moutsatsou, A.K., Baklavaridis, A.N., Katsika, E.L. and Domopoulou, A.E. (2017), "Synergistic Sintering of Lignite Fly Ash and Steelmaking Residues towards Sustainable Compacted Ceramics", Advances in Materials Science and Engineering, Vol. 2017 No 1735268, p.8. https://doi.org/10.1155/2017/1735268

Kibert, C.J. (2016), Sustainable construction: green building design and delivery, John Wiley \& Sons, Hoboken, New Jersey.

Kirchherr, J., Reike, D. and Hekkert, M. (2017), "Conceptualizing the circular economy: An analysis of 114 definitions", Resources, Conservation and Recycling, Vol. 127, pp.221-232. https://doi.org/10.1016/j.resconrec.2017.09.005

Kylili, A. and Fokaides, P.A. (2017), "Policy trends for the sustainability assessment of construction materials: A review", Sustainable Cities and Society, Vol. 35, pp.280-288. https://doi.org/10.1016/j.scs.2017.08.013

Lai, X., Liu, J., Shi, Q., Georgiev, G. and Wu, G. (2017), "Driving forces for low carbon technology innovation in the building industry: A critical review", Renewable and Sustainable Energy Reviews, Vol. 74, pp.299-315. https://doi.org/10.1016/j.rser.2017.02.044

Leising, E., Quist, J. and Bocken, N. (2018), "Circular Economy in the building sector: Three cases and a collaboration tool", Journal of Cleaner production, Vol. 176, pp.976-989. https://doi.org/10.1016/j.jclepro.2017.12.010 
Lemougna, P.N., Melo, U.F.C., Kamseu, E. and Tchamba, A.B. (2011), "Laterite based stabilized products for sustainable building applications in tropical countries: review and prospects for the case of Cameroon", Sustainability, Vol. 3 No. 1, pp.293-305. https://doi.org/10.3390/su3010293

Lieder, M. and Rashid, A. (2016), "Towards circular economy implementation: a comprehensive review in context of manufacturing industry", Journal of cleaner production, Vol. 115, pp.36-51. https://doi.org/10.1016/j.jclepro.2015.12.042

López-Uceda, A., Galvín, A.P., Ayuso, J., Jiménez, J.R., Vanwalleghem, T. and Peña, A. (2018), "Risk assessment by percolation leaching tests of extensive green roofs with fine fraction of mixed recycled aggregates from construction and demolition waste", Environmental Science and Pollution Research, Vol. 25 No. 36, pp.36024-36034. https://doi.org/10.1007/s11356-018-1703-1

MacArthur, E. (2013), "Towards the circular economy", Journal of Industrial Ecology, Vol. 2, pp.23-44. https://www.werktrends.nl/app/uploads/2015/06/Rapport McKinseyTowards_A_Circular_Economy.pdf (accessed 20 November 2019).

Mahpour, A. (2018), "Prioritizing barriers to adopt circular economy in construction and demolition waste management", Resources, Conservation and Recycling, Vol. 134, pp.216-227. https://doi.org/10.1016/j.resconrec.2018.01.026

Mariano, E.B., Sobreiro, V.A. and do Nascimento Rebelatto, D.A. (2015), "Human development and data envelopment analysis: A structured literature review", Omega, Vol. 54, pp.33-49. https://doi.org/10.1016/j.omega.2015.01.002

Mihai, F.C. (2019), "Construction and demolition waste in Romania: The route from illegal dumping to building materials", Sustainability, Vol. 11 No. 11, p.3179. https://doi.org/10.3390/su11113179

Minunno, R., O'Grady, T., Morrison, G., Gruner, R. and Colling, M. (2018), "Strategies for applying the circular economy to prefabricated buildings", Buildings, Vol. 8 No. 9, p.125. https://doi.org/10.3390/buildings 8090125 
Mitchell, P. and James, K. (2015), "Economic growth potential of more circular economies", working paper, Waste and Resources Action Programme, Banbury, UK, available

at:

https://www.researchgate.net/profile/Peter_Mitchell21/publication/284187253_E CONOMIC_GROWTH_POTENTIAL_OF_MORE_CIRCULAR_ECONOMIES/links/564f4 Ofb08ae1ef9296e83f3.pdf (accessed 02 December 2019).

Mobili, A., Giosuè, C. and Tittarelli, F. (2018), "Valorisation of GRP dust waste in fired clay bricks", Advances in Civil Engineering, Vol. 2018, No. 5256741, https://doi.org/10.1155/2018/5256741

Mohamed Abdul Ghani, N.M.A., Egilmez, G., Kucukvar, M. and S. Bhutta, M.K. (2017), "From green buildings to green supply chains: An integrated input-output life cycle assessment and optimization framework for carbon footprint reduction policy making", Management of Environmental Quality, Vol. 28 No. 4, pp. 532548. https://doi.org/10.1108/MEQ-12-2015-0211

Nasir, M.H.A., Genovese, A., Acquaye, A.A., Koh, S.C.L. and Yamoah, F. (2017), "Comparing linear and circular supply chains: A case study from the construction industry", International Journal of Production Economics, Vol. 183, pp.443-457. DOI: https://doi.org/10.1016/j.ijpe.2016.06.008

Nuñez-Cacho, P., Górecki, J., Molina-Moreno, V. and Corpas-Iglesias, F. (2018), "What gets measured, gets done: Development of a circular economy measurement scale for building industry", Sustainability, Vol. 10(7), p.2340. https://doi.org/10.3390/su10072340

Omotayo, T. and Kulatunga, U. (2015), "The research methodology for the development of a kaizen costing framework suitable for indigenous construction firms in Lagos Nigeria", in Proceedings of ARCOM Doctoral Workshop Research Methodology, Dublin Institute of Technology, pp.1-12, available at: http://www.arcom.ac.uk/-docs/workshops/2015-04_Dublin-Proceedings.pdf (assessed 05 January 2020).

Omotayo, T.S., Boateng, P., Osobajo, O., Oke, A. and Obi, L.I. (2019), "Systems thinking and CMM for continuous improvement in the construction industry", 
International Journal of Productivity and Performance Management, Vol. 69 No. 2, pp. 271-296. https://doi.org/10.1108/IJPPM-11-2018-0417

Ortiz, O., Castells, F. and Sonnemann, G. (2009), "Sustainability in the construction industry: A review of recent developments based on LCA", Construction and building materials, Vol. 23 No. 1, pp.28-39. https://doi.org/10.1016/j.conbuildmat.2007.11.012

Osobajo, O.A. and Moore, D. (2017), "Methodological choices in relationship quality (RQ) research 1987 to 2015: a systematic literature review", Journal of Relationship Marketing, Vol. 16 No. 1, pp.40-81. https://doi.org/10.1080/15332667.2016.1242395

Pan, S.Y., Du, M.A., Huang, I.T., Liu, I.H., Chang, E.E. and Chiang, P.C. (2015), "Strategies on implementation of waste-to-energy (WTE) supply chain for circular economy system: a review", Journal of Cleaner Production, Vol. 108, pp.409-421. https://doi.org/10.1016/j.jclepro.2015.06.124

Pearce, D.W. and Turner, R.K. (1990), Economics of Natural Resources and the Environment, Hemel Hempstead: Harvester Wheatsheaf.

Pelz, M. (2019), "Can Management Accounting Be Helpful for Young and Small Companies? Systematic Review of a Paradox", International Journal of Management Reviews, Vol. 21 No. 2, pp.256-274. https://doi.org/10.1111/ijmr.12197

Pomponi, F. and Moncaster, A. (2017), "Circular economy for the built environment: A research framework", Journal of Cleaner Production, Vol. 143, pp.710-718. https://doi.org/10.1016/j.jclepro.2016.12.055

Preston, F. (2012), A global redesign?: Shaping the circular economy. London: Chatham House. Available at: https://www.chathamhouse.org/publications/papers/view/182376/bp0312_prest on.pdf

Raouf, A.M. and Al-Ghamdi, S.G. (2019), "Building information modelling and green buildings: challenges and opportunities", Architectural Engineering and 
Design Management, Vol. 15 No. 1, pp.1-28. https://doi.org/10.1080/17452007.2018.1502655

Rose, C.M. and Stegemann, J.A. (2018), "From waste management to component management in the construction industry", Sustainability, Vol. 10 No. 1, p.229. https://doi.org/10.3390/su10010229

Sanchez, B., Esfahani, M.E. and Haas, C. (2019), "A methodology to analyze the net environmental impacts and building's cost performance of an adaptive reuse project: a case study of the Waterloo County Courthouse renovations", Environment Systems and Decisions, Vol. 39 No. 4, pp.419-438. https://doi.org/10.1007/s10669-019-09734-2

Schiller, G., Gruhler, K. and Ortlepp, R. (2017), "Continuous material flow analysis approach for bulk nonmetallic mineral building materials applied to the German building sector", Journal of Industrial Ecology, Vol. 21 No. 3, pp.673-688. https://doi.org/10.1111/jiec.12595

Schroeder, P., Anggraeni, K. and Weber, U. (2019), "The relevance of circular economy practices to the sustainable development goals", Journal of Industrial Ecology, Vol. 23 No. 1, pp.77-95. https://doi.org/10.1111/jiec.12732

Sfakianaki, E. (2015), "Resource-efficient construction: rethinking construction towards sustainability", World Journal of Science, Technology and Sustainable Development, Vol. 12 No. 3, pp. 233-242. https://doi.org/10.1108/WJSTSD-032015-0016

Sierra-Pérez, J., García-Pérez, S., Blanc, S., Boschmonart-Rives, J. and Gabarrell, $X$. (2018), "The use of forest-based materials for the efficient energy of cities: Environmental and economic implications of cork as insulation material", Sustainable cities and society, Vol. 37, pp.628-636. https://doi.org/10.1016/j.scs.2017.12.008

Silva, R.V., de Brito, J. and Dhir, R.K. (2019), "Use of recycled aggregates arising from construction and demolition waste in new construction applications", Journal of Cleaner Production, Vol. 236, p.117629. https://doi.org/10.1016/j.jclepro.2019.117629 
Smol, M., Kulczycka, J., Henclik, A., Gorazda, K. and Wzorek, Z. (2015), "The possible use of sewage sludge ash (SSA) in the construction industry as a way towards a circular economy", Journal of Cleaner Production, Vol. 95, pp.45-54. https://doi.org/10.1016/j.jclepro.2015.02.051

Su, B., Heshmati, A., Geng, Y. and Yu, X. (2013), "A review of the circular economy in China: moving from rhetoric to implementation", Journal of cleaner production, Vol. 42, pp.215-227. https://doi.org/10.1016/j.jclepro.2012.11.020

Tam, V.W., Tam, C.M. and Le, K.N. (2007), "Removal of cement mortar remains from recycled aggregate using pre-soaking approaches", Resources, Conservation and Recycling, Vol. 50 No. 1, pp.82-101. https://doi.org/10.1016/j.resconrec.2006.05.012

Thorley, J., Garza-Reyes, J.A. and Anosike, A. (2019), "The circular economy impact on small to medium enterprises", Waste Management and the Environment, Vol. IX No. 231, p.257, available at: https://books.google.co.uk/books?hl=en\&lr=\&id=ysqFDwAAQBAJ\&oi=fnd\&pg=P A257\&dq $=$ The +circular+economy+impact+on+small+to+medium+enterprises. + \&ots=Lev_6yLcvS\&sig=QmpSRXm-

ZnLyoavIsWKwbJZ5KkQ\&redir esc $=y \# v=$ onepage\&q $=$ The\%20circular\%20econo my\%20impact\%20on\%20small\%20to\%20medium\%20enterprises. \&f=false

Tingley, D.D., Cooper, S. and Cullen, J. (2017), "Understanding and overcoming the barriers to structural steel reuse, a UK perspective", Journal of Cleaner Production, Vol. 148, pp.642-652. https://doi.org/10.1016/j.jclepro.2017.02.006

Tong, X. and Tao, D., (2016), "The rise and fall of a "waste city" in the construction of an "urban circular economic system": The changing landscape of waste in Beijing", Resources, Conservation and Recycling, Vol. 107, pp.10-17. https://doi.org/10.1016/j.resconrec.2015.12.003

Tukker, A. (2015), "Product services for a resource-efficient and circular economy-a review", Journal of cleaner production, Vol. 97, pp.76-91. https://doi.org/10.1016/j.jclepro.2013.11.049 
van Breugel, K. (2018), "How models can make a difference for a sustainable future of the building industry", Materials and structures, Vol. 51 No. 6, p.161. https://doi.org/10.1617/s11527-018-1287-8

van Dijk, S., Tenpierik, M. and van den Dobbelsteen, A. (2014), "Continuing the building's cycles: A literature review and analysis of current systems theories in comparison with the theory of Cradle to Cradle", Resources, Conservation and Recycling, Vol. 82, pp.21-34. https://doi.org/10.1016/j.resconrec.2013.10.007

Van Praagh, M., Johansson, M., Fagerqvist, J., Grönholm, R., Hansson, N. and Svensson, H. (2018), Recycling of MSWI-bottom ash in paved constructions in Sweden-A risk assessment. Waste management, 79, pp.428-434. https://doi.org/10.1016/j.wasman.2018.07.025

van Stijn, A. and Gruis, V. (2019), "Towards a circular built environment: An integral design tool for circular building components", Smart and Sustainable Built Environment. https://doi.org/10.1108/SASBE-05-2019-0063

Wang, Y., Sun, M., Wang, R. and Lou, F. (2015), "Promoting regional sustainability by eco-province construction in China: A critical assessment", Ecological indicators, Vol. 51, pp.127-138. https://doi.org/10.1016/j.ecolind.2014.07.003

WRAP. (2013), "Built Environment Circular Economy", available at: https://www.wrap.org.uk/sites/files/wrap/WRAP\%20Built\%20Environment\%20\%20Circular\%20Economy\%20Jan\%202013.pdf (accessed 20 November 2019).

Wuyts, W., Miatto, A., Sedlitzky, R. and Tanikawa, H. (2019), "Extending or ending the life of residential buildings in Japan: A social circular economy approach to the problem of short-lived constructions", Journal of cleaner production, Vol. 231, pp.660-670. https://doi.org/10.1016/j.jclepro.2019.05.258

Yu, A.T.W., Javed, A.A., Lam, T.I., Shen, G.Q. and Sun, M. (2018), "Integrating value management into sustainable construction projects in Hong Kong", Engineering, Construction and Architectural Management, Vol. 25 No. 11, pp.1475-1500. https://doi.org/10.1108/ECAM-03-2017-0049 
Yuan, F., Shen, L.Y. and Li, Q.M. (2011), "Emergy analysis of the recycling options for construction and demolition waste", Waste management, Vol. 31 No. 12, pp.2503-2511. https://doi.org/10.1016/j.wasman.2011.07.001

Zacho, K.O., Mosgaard, M. and Riisgaard, H. (2018), "Capturing Uncaptured Values-A Danish case study on municipal preparation for reuse and recycling of waste", Resources, Conservation and Recycling, Vol. 136, pp.297-305. https://doi.org/10.1016/j.resconrec.2018.04.031 
Table 1: Reviewed Journal

\begin{tabular}{|c|c|c|c|c|c|c|c|c|c|c|c|}
\hline No & Journal Name & 2007 & 2011 & 2013 & 2014 & 2015 & 2016 & 2017 & 2018 & 2019 & Total \\
\hline 1 & $\begin{array}{l}\text { Journal of } \\
\text { Industrial } \\
\text { Ecology }\end{array}$ & 1 & & & & & & 1 & & & 2 \\
\hline 2 & $\begin{array}{l}\text { Resources, } \\
\text { Conservation and } \\
\text { Recycling }\end{array}$ & 1 & & 1 & & & 1 & & 3 & 1 & 7 \\
\hline 3 & Sustainability & & 1 & & & & & 1 & 1 & 1 & 4 \\
\hline 4 & $\begin{array}{l}\text { Waste } \\
\text { management }\end{array}$ & & 1 & & & & & & 1 & & 2 \\
\hline 5 & $\begin{array}{l}\text { Environment, } \\
\text { development and } \\
\text { sustainability }\end{array}$ & & & & 1 & & & & & & 1 \\
\hline 6 & $\begin{array}{l}\text { Ecological } \\
\text { indicators }\end{array}$ & & & & 1 & 1 & & & & & 2 \\
\hline 7 & $\begin{array}{l}\text { Technology in } \\
\text { Society }\end{array}$ & & & & 1 & & & & & & 1 \\
\hline 8 & Ambio & & & & 1 & & & & & & 1 \\
\hline 9 & $\begin{array}{l}\text { World Journal of } \\
\text { Science, } \\
\text { Technology and } \\
\text { Sustainable } \\
\text { Development }\end{array}$ & & & & & 1 & & & & & 1 \\
\hline 10 & $\begin{array}{l}\text { Journal of } \\
\text { Cleaner } \\
\text { Production }\end{array}$ & & & & & 1 & 1 & 1 & 2 & 3 & 8 \\
\hline 11 & Energy procedia & & & & & & 1 & & & & 1 \\
\hline 12 & $\begin{array}{l}\text { Journal of } \\
\text { Material Cycles } \\
\text { and Waste } \\
\text { Management }\end{array}$ & & & & & & & 1 & & & 1 \\
\hline 13 & $\begin{array}{l}\text { Management of } \\
\text { Environmental } \\
\text { Quality: An } \\
\text { International } \\
\text { Journal }\end{array}$ & & & & & & & 1 & & & 1 \\
\hline
\end{tabular}


14 Advances in

Materials Science

and Engineering

15 Sustainable

Cities and

Society

16 Renewable and

Sustainable

Energy Reviews

17 International

Journal of

Production

Economics

18 Acta Structilia

19 Environmental

Science and

Pollution

Research

20 Clean

Technologies and

Environmental

Policy

21 Building

22 Advances in Civil

Engineering

23 Materials and structures

24 Engineering,

Construction and

Architectural

Management

25 Engineering

structures

26 Construction and

Building

Materials

27 The International Journal of Life 


\section{Cycle}

Assessment

28 Architectural

Engineering and

Design

Management

29 Environment

1

Systems and

Decisions 
Table 2:

\section{Authors}

Fernandez (2007)

Yuan et al. (2011)

Dean et al. (2014)

Smol et al. (2015)

Wang et al. (2015)

Esa et al. (2017)

Nasir et al. (2017)

Ghisellini et al. (2018)

\section{CE Definition}

It entails activities that both supports economic growth and facilitates the closing of material loops and the overall promotion of resource efficiency.

Is the flow of raw material to product, then not to waste in the environment but to regenerated product

It is aimed at improving the efficiency of materials and energy use.

It is keeping the added value in products to eliminate waste.

Is the transformation of resources to products to regenerated resources mode.

It is an approach for waste minimization throughout the overall construction cycle.

It pushes for a closed-loop supply chain design, enabling any products at the end of their life cycle to re-enter the supply chain as a production input.

Is a new model of economic development that promotes the maximum reuse/recycling of materials, goods and components in order to decrease waste generation to the largest possible extent.

Akanbi et al. (2018); Huang et al. Is reducing, reuse and recycling of materials.

(2018); Minunno et al. (2018)

Leising et al. (2018)

Mahpour (2018)

Sierra-Pérez et al. (2018)
Is a system where material loops are closed and slowed and value creation is aimed for at every chain in the system

A system that is restorative or regenerative by intention and design to replace the end-of-life concept with restoration.

It optimises raw material use to minimise environmental impacts. 


\section{Appendices}

Appendix 1: List of academic peer-reviewed journal articles

\begin{tabular}{|c|c|c|c|c|c|}
\hline Author(s) & Journal Title & $\begin{array}{l}\text { Study } \\
\text { Focus }\end{array}$ & Type of Study & $\begin{array}{l}\text { Method of } \\
\text { Data } \\
\text { Collection }\end{array}$ & Study Context \\
\hline $\begin{array}{l}\text { Fernandez } \\
(2007)\end{array}$ & $\begin{array}{l}\text { Journal of Industrial } \\
\text { Ecology }\end{array}$ & $\begin{array}{l}\text { Material } \\
\text { reuse }\end{array}$ & Empirical & Questionnaire & China \\
\hline $\begin{array}{l}\text { Tam, Tam } \\
\text { and Le } \\
\text { (2007) }\end{array}$ & $\begin{array}{l}\text { Resources, } \\
\text { Conservation and } \\
\text { Recycling }\end{array}$ & $\begin{array}{l}\text { Waste } \\
\text { management }\end{array}$ & Empirical & Experiment & Australia and China \\
\hline $\begin{array}{l}\text { Lemougna et } \\
\text { al. (2011) }\end{array}$ & Sustainability & $\begin{array}{l}\text { Material } \\
\text { reuse }\end{array}$ & Theoretical & $\begin{array}{l}\text { Literature } \\
\text { review }\end{array}$ & Cameroon \\
\hline $\begin{array}{l}\text { Yuan, Shen } \\
\text { and Li } \\
\text { (2011) }\end{array}$ & Waste management & $\begin{array}{l}\text { Waste } \\
\text { management }\end{array}$ & Empirical & Case study & China \\
\hline $\begin{array}{l}\text { Huang et al. } \\
(2013)\end{array}$ & $\begin{array}{l}\text { Resources, } \\
\text { Conservation and } \\
\text { Recycling }\end{array}$ & $\begin{array}{l}\text { Material } \\
\text { reuse }\end{array}$ & Theoretical & $\begin{array}{l}\text { Literature } \\
\text { review }\end{array}$ & China \\
\hline $\begin{array}{l}\text { Atolagbe and } \\
\text { Fadamiro } \\
\text { (2014) }\end{array}$ & $\begin{array}{l}\text { Environment, } \\
\text { development and } \\
\text { sustainability }\end{array}$ & $\begin{array}{l}\text { Material } \\
\text { reuse }\end{array}$ & Theoretical & $\begin{array}{l}\text { Literature } \\
\text { review }\end{array}$ & Nigeria \\
\hline $\begin{array}{l}\text { Dean, Fath } \\
\text { and Chen, } \\
(2014)\end{array}$ & Ecological indicators & CE model & Empirical & Case study & USA and China \\
\hline $\begin{array}{l}\text { He et al. } \\
(2014)\end{array}$ & Technology in Society & $\begin{array}{l}\text { Energy } \\
\text { efficiency }\end{array}$ & Theoretical & $\begin{array}{l}\text { Literature } \\
\text { review }\end{array}$ & China \\
\hline $\begin{array}{l}\text { Hong et al. } \\
\text { (2014) }\end{array}$ & Ambio & Land use & Theoretical & $\begin{array}{l}\text { Literature } \\
\text { review }\end{array}$ & China \\
\hline $\begin{array}{l}\text { Sfakianaki } \\
(2015)\end{array}$ & $\begin{array}{l}\text { World Journal of } \\
\text { Science, Technology } \\
\text { and Sustainable } \\
\text { Development }\end{array}$ & $\begin{array}{l}\text { Material } \\
\text { reuse }\end{array}$ & Theoretical & $\begin{array}{l}\text { Literature } \\
\text { review }\end{array}$ & Greece \\
\hline $\begin{array}{l}\text { Smol et al. } \\
\text { (2015) }\end{array}$ & $\begin{array}{l}\text { Journal of Cleaner } \\
\text { Production }\end{array}$ & $\begin{array}{l}\text { Waste } \\
\text { management }\end{array}$ & Theoretical & $\begin{array}{l}\text { Literature } \\
\text { review }\end{array}$ & Poland \\
\hline $\begin{array}{l}\text { Wang et al. } \\
\text { (2015) }\end{array}$ & Ecological indicators & CE model & Empirical & Case study & China \\
\hline $\begin{array}{l}\text { Chang et al. } \\
(2016)\end{array}$ & $\begin{array}{l}\text { Journal of Cleaner } \\
\text { Production }\end{array}$ & Policy & Theoretical & $\begin{array}{l}\text { Literature } \\
\text { review }\end{array}$ & China \\
\hline $\begin{array}{l}\text { Geldermans } \\
\text { (2016) }\end{array}$ & Energy procedia & $\begin{array}{l}\text { Material } \\
\text { reuse }\end{array}$ & Empirical & Workshops & Netherlands \\
\hline $\begin{array}{l}\text { Tong and } \\
\text { Tao }(2016)\end{array}$ & $\begin{array}{l}\text { Resources, } \\
\text { Conservation and } \\
\text { Recycling } \\
\end{array}$ & $\begin{array}{l}\text { Waste } \\
\text { management }\end{array}$ & Theoretical & $\begin{array}{l}\text { Literature } \\
\text { review }\end{array}$ & China \\
\hline $\begin{array}{l}\text { Esa, Halog } \\
\text { and } \\
\text { Rigamonti } \\
\text { (2017) }\end{array}$ & $\begin{array}{l}\text { Journal of Material } \\
\text { Cycles and Waste } \\
\text { Management }\end{array}$ & $\begin{array}{l}\text { Waste } \\
\text { management }\end{array}$ & Theoretical & $\begin{array}{l}\text { Literature } \\
\text { review }\end{array}$ & Malaysia \\
\hline $\begin{array}{l}\text { Mohamed } \\
\text { Abdul Ghani } \\
\text { et al. (2017) }\end{array}$ & $\begin{array}{l}\text { Management of } \\
\text { Environmental } \\
\text { Quality: An } \\
\text { International Journal }\end{array}$ & Supply chain & Empirical & Case study & USA \\
\hline $\begin{array}{l}\text { Jiménez- } \\
\text { Rivero, de } \\
\text { Guzmán- } \\
\text { Báez and } \\
\text { García- } \\
\text { Navarro } \\
\text { (2017) }\end{array}$ & Suatainability & $\begin{array}{l}\text { Waste } \\
\text { management }\end{array}$ & Empirical & $\begin{array}{l}\text { Case study and } \\
\text { face-to-face } \\
\text { structured } \\
\text { interviews }\end{array}$ & Spain \\
\hline $\begin{array}{l}\text { Karayannis } \\
\text { et al. (2017) }\end{array}$ & $\begin{array}{l}\text { Advances in Materials } \\
\text { Science and } \\
\text { Engineering }\end{array}$ & $\begin{array}{l}\text { Waste } \\
\text { management }\end{array}$ & Empirical & Experiment & Greece \\
\hline $\begin{array}{l}\text { Kylili and } \\
\text { Fokaides } \\
\text { (2017) }\end{array}$ & $\begin{array}{l}\text { Sustainable Cities } \\
\text { and Society }\end{array}$ & Policy & Theoretical & $\begin{array}{l}\text { Literature } \\
\text { review }\end{array}$ & Europe \\
\hline
\end{tabular}




\begin{tabular}{|c|c|c|c|c|c|}
\hline $\begin{array}{l}\text { Lai et al. } \\
\text { (2017) }\end{array}$ & $\begin{array}{l}\text { Renewable and } \\
\text { Sustainable Energy } \\
\text { Reviews }\end{array}$ & $\begin{array}{l}\text { Energy } \\
\text { efficiency }\end{array}$ & Empirical & $\begin{array}{l}\text { Questionnaire } \\
\text { and telephone } \\
\text { interview }\end{array}$ & China \\
\hline $\begin{array}{l}\text { Schiller } \\
\text { Gruhler and } \\
\text { Ortlepp } \\
(2017)\end{array}$ & $\begin{array}{l}\text { Journal of Industrial } \\
\text { Ecology }\end{array}$ & Supply chain & Empirical & Case study & Germany \\
\hline $\begin{array}{l}\text { Tingley, } \\
\text { Cooper and } \\
\text { Cullen } \\
(2017)\end{array}$ & $\begin{array}{l}\text { Journal of Cleaner } \\
\text { Production }\end{array}$ & $\begin{array}{l}\text { Material } \\
\text { reuse }\end{array}$ & Empirical & $\begin{array}{l}\text { Semi-structured } \\
\text { interview }\end{array}$ & UK \\
\hline $\begin{array}{l}\text { Nasir et al. } \\
(2017)\end{array}$ & $\begin{array}{l}\text { International Journal } \\
\text { of Production } \\
\text { Economics }\end{array}$ & Supply chain & Empirical & $\begin{array}{l}\text { Casse study and } \\
\text { interview }\end{array}$ & UK \\
\hline $\begin{array}{l}\text { Akanbi et al. } \\
(2018)\end{array}$ & $\begin{array}{l}\text { Resources, } \\
\text { Conservation and } \\
\text { Recycling }\end{array}$ & $\begin{array}{l}\text { Material } \\
\text { reuse }\end{array}$ & Empirical & Case study & UK \\
\hline $\begin{array}{l}\text { Aneke and } \\
\text { Awuzie } \\
\text { (2018) }\end{array}$ & Acta Structilia & $\begin{array}{l}\text { Waste } \\
\text { management }\end{array}$ & Empirical & $\begin{array}{l}\text { Case study and } \\
\text { experiment }\end{array}$ & South Africa \\
\hline $\begin{array}{l}\text { de Freitas et } \\
\text { al. (2018) }\end{array}$ & $\begin{array}{l}\text { Clean Technologies } \\
\text { and Environmental } \\
\text { Policy }\end{array}$ & $\begin{array}{l}\text { Material } \\
\text { reuse }\end{array}$ & Empirical & Experiment & Brazil \\
\hline $\begin{array}{l}\text { Ghisellini, } \\
\text { Ripa and } \\
\text { Ulgiati } \\
\text { (2018) }\end{array}$ & $\begin{array}{l}\text { Journal of Cleaner } \\
\text { production }\end{array}$ & $\begin{array}{l}\text { Material } \\
\text { reuse }\end{array}$ & Theoretical & $\begin{array}{l}\text { Literature } \\
\text { review }\end{array}$ & $\begin{array}{l}\text { Italy, Spain and } \\
\text { China }\end{array}$ \\
\hline $\begin{array}{l}\text { Huang et al. } \\
\text { (2018) }\end{array}$ & $\begin{array}{l}\text { Resources, } \\
\text { Conservation and } \\
\text { Recycling }\end{array}$ & $\begin{array}{l}\text { Waste } \\
\text { management }\end{array}$ & Empirical & Interview & China \\
\hline $\begin{array}{l}\text { Leising, } \\
\text { Quist and } \\
\text { Bocken } \\
(2018)\end{array}$ & $\begin{array}{l}\text { Journal of Cleaner } \\
\text { production }\end{array}$ & Supply chain & Empirical & Case study & Netherlands \\
\hline $\begin{array}{l}\text { López-Uceda } \\
\text { et al. (2018) }\end{array}$ & $\begin{array}{l}\text { Environmental } \\
\text { Science and Pollution } \\
\text { Research }\end{array}$ & $\begin{array}{l}\text { Material } \\
\text { reuse }\end{array}$ & Empirical & Experiment & Spain \\
\hline $\begin{array}{l}\text { Mahpour } \\
\text { (2018) }\end{array}$ & $\begin{array}{l}\text { Resources, } \\
\text { Conservation and } \\
\text { Recycling }\end{array}$ & $\begin{array}{l}\text { Waste } \\
\text { management }\end{array}$ & Empirical & $\begin{array}{l}\text { Semi-structured } \\
\text { interview }\end{array}$ & Iran \\
\hline $\begin{array}{l}\text { Minunno et } \\
\text { al. (2018) }\end{array}$ & Building & $\begin{array}{l}\text { Material } \\
\text { reuse }\end{array}$ & Theoretical & $\begin{array}{l}\text { Literature } \\
\text { review }\end{array}$ & Australia \\
\hline $\begin{array}{l}\text { Mobili, } \\
\text { Giosuè and } \\
\text { Tittarelli } \\
(2018)\end{array}$ & $\begin{array}{l}\text { Advances in Civil } \\
\text { Engineering }\end{array}$ & $\begin{array}{l}\text { Material } \\
\text { reuse }\end{array}$ & Empirical & Experiment & Italy \\
\hline $\begin{array}{l}\text { Nuñez- } \\
\text { Cacho et al. } \\
(2018)\end{array}$ & Sustainability & CE model & Empirical & Questionnaire & $\begin{array}{l}\text { Germany, Spain, } \\
\text { Poland, China, } \\
\text { Great Britain, USA, } \\
\text { Italy and the } \\
\text { Netherlands }\end{array}$ \\
\hline $\begin{array}{l}\text { Sierra-Pérez } \\
\text { et al. (2018) }\end{array}$ & $\begin{array}{l}\text { Sustainable cities and } \\
\text { society }\end{array}$ & Material use & Empirical & Experiment & Spain \\
\hline $\begin{array}{l}\text { van Breugel } \\
(2018)\end{array}$ & $\begin{array}{l}\text { Materials and } \\
\text { structures }\end{array}$ & CE model & Theoretical & $\begin{array}{l}\text { Literature } \\
\text { review }\end{array}$ & Netherlands \\
\hline $\begin{array}{l}\text { Van Praagh } \\
\text { et al. (2018) }\end{array}$ & Waste Management & $\begin{array}{l}\text { Waste } \\
\text { management }\end{array}$ & Empirical & Experiment & Sweden \\
\hline $\begin{array}{l}\text { Yu et al } \\
\text { (2018) }\end{array}$ & $\begin{array}{l}\text { Engineering, } \\
\text { Construction and } \\
\text { Architectural } \\
\text { Management }\end{array}$ & $\begin{array}{l}\text { Building } \\
\text { designs }\end{array}$ & Empirical & $\begin{array}{l}\text { Questionnaire } \\
\text { and semi- } \\
\text { structured } \\
\text { interviews }\end{array}$ & Hong Kong \\
\hline $\begin{array}{l}\text { Akinade and } \\
\text { Oyedele } \\
\text { (2019) }\end{array}$ & $\begin{array}{l}\text { Journal of Cleaner } \\
\text { production }\end{array}$ & $\begin{array}{l}\text { Waste } \\
\text { management }\end{array}$ & Empirical & $\begin{array}{l}\text { Case study and } \\
\text { experiment }\end{array}$ & UK \\
\hline $\begin{array}{l}\text { Almirall et } \\
\text { al. (2019) }\end{array}$ & $\begin{array}{l}\text { Engineering } \\
\text { structures }\end{array}$ & Policy & Empirical & Case study & Spain \\
\hline $\begin{array}{l}\text { Chen et al. } \\
(2019)\end{array}$ & $\begin{array}{l}\text { Construction and } \\
\text { Building Materials }\end{array}$ & $\begin{array}{l}\text { Material } \\
\text { reuse }\end{array}$ & Theoretical & $\begin{array}{l}\text { Literature } \\
\text { review }\end{array}$ & $\begin{array}{l}\text { China, UK and } \\
\text { Germany }\end{array}$ \\
\hline
\end{tabular}




\begin{tabular}{|c|c|c|c|c|c|}
\hline $\begin{array}{l}\text { Chiang, Yen } \\
\text { and Lu } \\
\text { (2019) }\end{array}$ & $\begin{array}{l}\text { Environmental } \\
\text { Science and Pollution } \\
\text { Research }\end{array}$ & $\begin{array}{l}\text { Waste } \\
\text { management }\end{array}$ & Empirical & Experiment & Taiwan \\
\hline $\begin{array}{l}\text { Corradini, } \\
\text { Pierobon and } \\
\text { Zanetti } \\
(2019)\end{array}$ & $\begin{array}{l}\text { The International } \\
\text { Journal of Life Cycle } \\
\text { Assessment }\end{array}$ & $\begin{array}{l}\text { Material } \\
\text { reuse }\end{array}$ & Empirical & Case study & Italy \\
\hline $\begin{array}{l}\text { Hossain et } \\
\text { al. (2019) }\end{array}$ & $\begin{array}{l}\text { Resources, } \\
\text { Conservation and } \\
\text { Recycling }\end{array}$ & $\begin{array}{l}\text { Waste } \\
\text { management }\end{array}$ & Empirical & $\begin{array}{l}\text { Literature } \\
\text { review }\end{array}$ & Hong Kong \\
\hline Mihai (2019) & Sustainability & $\begin{array}{l}\text { Waste } \\
\text { management }\end{array}$ & Empirical & Observation & Romania \\
\hline $\begin{array}{l}\text { Raouf and } \\
\text { Al-Ghamdi } \\
\text { (2019) }\end{array}$ & $\begin{array}{l}\text { Architectural } \\
\text { Engineering and } \\
\text { Design Management }\end{array}$ & $\begin{array}{l}\text { Building } \\
\text { designs }\end{array}$ & Theoretical & $\begin{array}{l}\text { Literature } \\
\text { review }\end{array}$ & Qatar \\
\hline $\begin{array}{l}\text { Sanchez, } \\
\text { Esfahani and } \\
\text { Haas (2019) }\end{array}$ & $\begin{array}{l}\text { Environment Systems } \\
\text { and Decisions }\end{array}$ & $\begin{array}{l}\text { Building } \\
\text { designs }\end{array}$ & Empirical & Case study & Canada \\
\hline $\begin{array}{l}\text { Silva, de } \\
\text { Brito and } \\
\text { Dhir (2019) }\end{array}$ & $\begin{array}{l}\text { Journal of Cleaner } \\
\text { production }\end{array}$ & $\begin{array}{l}\text { Material } \\
\text { reuse }\end{array}$ & Empirical & Case study & $\begin{array}{l}\text { Developed and } \\
\text { Developing }\end{array}$ \\
\hline $\begin{array}{l}\text { Wuyts et al. } \\
\text { (2019) }\end{array}$ & $\begin{array}{l}\text { Journal of Cleaner } \\
\text { production }\end{array}$ & CE model & Empirical & $\begin{array}{l}\text { Field visit and } \\
\text { expert } \\
\text { interviews }\end{array}$ & Japan \\
\hline
\end{tabular}


Appendix 2: Reviewed Journal Findings

\begin{tabular}{|c|c|}
\hline Author(s) & Contribution \\
\hline Fernandez (2007) & $\begin{array}{c}\text { Examined the consumption of material resources and concluded } \\
\text { that there is a need to formulate strategies for a circular } \\
\text { economy that include a resource-efficient. }\end{array}$ \\
\hline $\begin{array}{l}\text { Tam, Tam and Le } \\
\text { (2007) }\end{array}$ & $\begin{array}{l}\text { The authors proposed that the values of water absorption of the } \\
\text { pre-treated recycled aggregate in construction have to be } \\
\text { significantly reduced with improved mechanical properties to be } \\
\text { recyclable. }\end{array}$ \\
\hline $\begin{array}{l}\text { Lemougna et al. } \\
\text { (2011) }\end{array}$ & $\begin{array}{l}\text { The authors concluded that laterite can contribute to solving the } \\
\text { problem of affordable housing and providing environmentally- } \\
\text { friendly. }\end{array}$ \\
\hline $\begin{array}{l}\text { Yuan, Shen and Li } \\
\text { (2011) }\end{array}$ & $\begin{array}{c}\text { In an attempt to evaluate the efficiency of recycling construction } \\
\text { and demolition waste, the study demonstrated that the close- } \\
\text { loop recycling option is better than the open-loop recycling } \\
\text { option for construction and demolition waste. }\end{array}$ \\
\hline Huang et al. (2013) & $\begin{array}{c}\text { The outcome of the study indicated effective material reuse } \\
\text { influences materials demand and related } \mathrm{CO} 2 \text { emissions for new } \\
\text { buildings construction }\end{array}$ \\
\hline $\begin{array}{l}\text { Atolagbe and } \\
\text { Fadamiro (2014) }\end{array}$ & $\begin{array}{c}\text { The authors proposed five major factors of sustainability to } \\
\text { justify the use of sustainable material of both housing and } \\
\text { environmental developments. }\end{array}$ \\
\hline $\begin{array}{l}\text { Dean, Fath and Chen, } \\
(2014)\end{array}$ & $\begin{array}{c}\text { The authors concluded that an expanded business operations } \\
\text { model (EBOM) is essential assessing an a company's goal of } \\
\text { environmental stewardship. }\end{array}$ \\
\hline He et al. (2014) & $\begin{array}{l}\text { While assessing the overall context of energy efficiency in rural } \\
\text { China, the authors concluded that a new theoretical framework is } \\
\text { required to assist decision-makers in achieving energy efficiency. }\end{array}$ \\
\hline Hong et al. (2014) & $\begin{array}{c}\text { Pursuing sustainable development and building an ecological } \\
\text { civilization is imperative for the optimization of land use } \\
\text { patterns. }\end{array}$ \\
\hline Sfakianaki (2015) & $\begin{array}{c}\text { Examined the impact of material reuse on sustainable } \\
\text { construction to identify its importance and current thinking of the } \\
\text { concept. }\end{array}$ \\
\hline Smol et al. (2015) & $\begin{array}{l}\text { The authors affirmed that the construction industry will benefit } \\
\text { both economicallly and environmentally in the efficient use of } \\
\text { waste such as sewage sludge. }\end{array}$ \\
\hline Wang et al. (2015) & $\begin{array}{l}\text { The authors found that eco-efficiency indicators are essential for } \\
\text { ecological province contruction as the pre-set indicators are } \\
\text { inadequate. }\end{array}$ \\
\hline Chang et al. (2016) & $\begin{array}{c}\text { The authors identify strengthening technology innovation, } \\
\text { improving standards and evaluation, establishing demonstration } \\
\text { projects, and publicity are the key supporting activities for } \\
\text { sustainable construction. }\end{array}$ \\
\hline Geldermans (2016) & $\begin{array}{l}\text { Result shows that circularity-values emerge at the intersection of } \\
\text { specific intrinsic properties (material and product characteristics) } \\
\text { and relational properties (building design and use } \\
\text { characteristics), whilst combining multiple parameters for } \\
\text { reuseable materials. }\end{array}$ \\
\hline Tong and Tao (2016) & $\begin{array}{l}\text { It is impeartive to foster collaborative initiatives at the } \\
\text { community level to build an inclusive space for recycling } \\
\text { activities and promote waste management. }\end{array}$ \\
\hline
\end{tabular}


Esa, Halog and

Rigamonti (2017)

Mohamed Abdul Ghani et al. (2017)
Proposed a waste management framework based on the concept of circular economy for minimizing construction and demolition wastes.

Concluded that "ready-mix concrete manufacturing", "electric power generation, transmission and distribution" and "lighting fixture manufacturing" sectors were found to be the main culprits in the GHG emissions' stock. Hence, understanding the principles of "circular economy" within the context of sustainable development is necessary

Jiménez-Rivero, de Guzmán-Báez and García-Navarro (2017)

Result identified the management stages affecting the on-site production and management of plasterboard in a construction work and proposed best practices for an enhanced on-site waste management.

Karayannis et al. (2017)

The study produced sustainable ceramic materials derived from $100 \%$ industrial waste by-product mixtures based on circular economy concept.

Kylili and Fokaides (2017)

Concuded that the sustainability of the built environment will come through the increased use of alternative, recycled, natural and unconventional construction materials and thermal insulation materials.

\begin{tabular}{l|l} 
Lai et al. (2017) & Result revealed that system integration plays a crucial role in
\end{tabular} achieving low carbon development in the construction industry.

Schiller Gruhler and Ortlepp (2017)

Tingley, Cooper and Cullen (2017)

Nasir et al. (2017)

Akanbi et al. (2018) Study outcome revealed that building design with steel structure, demountable connections, and prefabricated assemblies produce recoverable materials that are mostly reusable.

Aneke and Awuzie (2018)

Concluded that the utilization of industrial wastes in the production of FA bricks did not only portray some outstanding characteristics but also showed potential to make salient contributions to society's sustainable aspirations.

Chiang, Yen and Lu (2018) Concluded that the feasibility of recycled gypsum board used as a swelling agent and good potential for construction works in green lightweight building materials.

de Freitas et al. (2018) Ghisellini, Ripa and Ulgiati (2018)

Huang et al. (2018) The study revealed that primary barriers to reducing construction

Leising, Quist and Bocken (2018) and demolition waste (CDW) in China are lack of building design standard for reducing CDW, low cost for CDW disposal and inappropriate urban planning.

The authors affirms that the management of solid waste contribute to sustainable development.

The study revealed that in most cases the circular econmy principle of reuse/recycling of construction and demolition waste at the end-of-life of a building as well as the production of
recycled products provide environmental and economic benefits. The authors affirms that developing circular buildings requires a new process design where a variety of disciplines in the supply chain is integrated upfront. 


\begin{tabular}{|c|c|}
\hline $\begin{array}{l}\text { López-Uceda et al. } \\
\text { (2018) }\end{array}$ & $\begin{array}{c}\text { The study revealed that releasing levels of polluting elements in } \\
\text { leachates have an important environmental-friendly potential in } \\
\text { the extensive green roof market, contributing to the circular } \\
\text { economy and urban sustainability. }\end{array}$ \\
\hline Mahpour (2018) & $\begin{array}{l}\text { Concluded that from behavioral, technical, and legal } \\
\text { perspectives, using finitely recyclable construction materials; } \\
\text { ineffective construction and demolition wastes dismantling, } \\
\text { sorting, transporting, and recovering processes; and using } \\
\text { finitely recyclable construction materials are the major barriers } \\
\text { to circular econmy transition. }\end{array}$ \\
\hline Minunno et al. (2018) & $\begin{array}{l}\text { The study revealed the potential of improving the circular } \\
\text { economy of buildings through prefabrication reduction, } \\
\text { reusability, adaptability and components recyclability. }\end{array}$ \\
\hline $\begin{array}{l}\text { Mobili, Giosuè and } \\
\text { Tittarelli (2018) }\end{array}$ & $\begin{array}{c}\text { Demonstrated that glass reinforced plastic dust (GRPd) addition } \\
\text { in FCBs production not only valorises GRPd waste and increases } \\
\text { sustainability of FCBs, but can also lead to an improvement of } \\
\text { some final performances of brick. }\end{array}$ \\
\hline $\begin{array}{l}\text { Nuñez-Cacho et al. } \\
\text { (2018) }\end{array}$ & $\begin{array}{l}\text { The authors designed a scale that will provide information on the } \\
\text { degree of long-term sustainability of the construction company, } \\
\text { and the degree of implementation of circular economy. }\end{array}$ \\
\hline $\begin{array}{l}\text { Sierra-Pérez et al. } \\
\text { (2018) }\end{array}$ & $\begin{array}{c}\text { The study result demonstrated a high potential of retrofit } \\
\text { buildings with resusing cork insulation boards from an } \\
\text { environmental and economic perspective. }\end{array}$ \\
\hline van Breugel (2018) & $\begin{array}{c}\text { The authors emphasised on the application of models for } \\
\text { sustainable solutions in the field of cementitious materials and } \\
\text { sustainable construction. }\end{array}$ \\
\hline $\begin{array}{l}\text { Van Praagh et al. } \\
\text { (2018) }\end{array}$ & $\begin{array}{c}\text { The study concluded that pre-treated municipal solid waste } \\
\text { incineration (MSWI) could be recycled in Sweden } \\
\text { in asphalt paved constructions with acceptable risks to } \\
\text { environment. }\end{array}$ \\
\hline Yu et & $\begin{array}{c}\text { The authors concluded that the value management of building } \\
\text { designs does provide opportunities to focus on issues relating to } \\
\text { sustainable society and environment. }\end{array}$ \\
\hline $\begin{array}{l}\text { Akinade and Oyedele } \\
\text { (2019) }\end{array}$ & $\begin{array}{l}\text { Using BIM principles, the authors developed a computational } \\
\text { approach to construction waste measurement. }\end{array}$ \\
\hline Almirall et al. (2019) & $\begin{array}{l}\text { The study outcome revealed that } \mathrm{f} \\
\text { key role in the sustainability }\end{array}$ \\
\hline Chen et al. (2019) & $\begin{array}{l}\text { The study summarized the existing research topics focusing on } \\
\text { recycled aggregate (RA), gaps of current research, suggestions } \\
\text { for promoting RA usage, and research directions for future work. }\end{array}$ \\
\hline Hossain et al. (2019) & $\begin{array}{c}\text { The study concluded that adopting resource recovery principle } \\
\text { can lead to } 37 \% \text { GHGs reduction from building. }\end{array}$ \\
\hline $\begin{array}{l}\text { Corradini, Pierob } \\
\text { and Zanetti ( } 20\end{array}$ & $\begin{array}{l}\text { The authors stated that the product environmental footprint } \\
\text { (PEF) methodology allows the identification of the main hotspots } \\
\text { and actions for reducing environmental impacts in existing } \\
\text { buidings. }\end{array}$ \\
\hline Mihai (2019) & $\begin{array}{c}\text { The study revealed that poor monitoring of construction and } \\
\text { demolition waste flows across Romanian counties and the } \\
\text { geographical dimension of this waste stream collected by waste } \\
\text { operators. }\end{array}$ \\
\hline Al-Ghamdi & $\begin{array}{c}\text { The authors identified the main obstacles and limitations to BIM } \\
\text { implementation in the green building industry. }\end{array}$ \\
\hline $\begin{array}{l}\text { Sanchez, Esfahani and } \\
\text { Haas (2019) }\end{array}$ & $\begin{array}{l}\text { The study revealed that the adaptive reuse of the building } \\
\text { structure produces a considerable decrease in the environmental } \\
\text { impacts and the construction building cost. }\end{array}$ \\
\hline
\end{tabular}


Silva, de Brito and Dhir (2019)

Wuyts et al. (2019)
The study highlighted the technical viability and appropriateness of using recycled aggregates in a broad range of construction applications.

The authors presented a framework for the identification of delayed, justified, or premature obsolescence. This framework can be used to decide whether the life of a residential building should be extended or ended. 


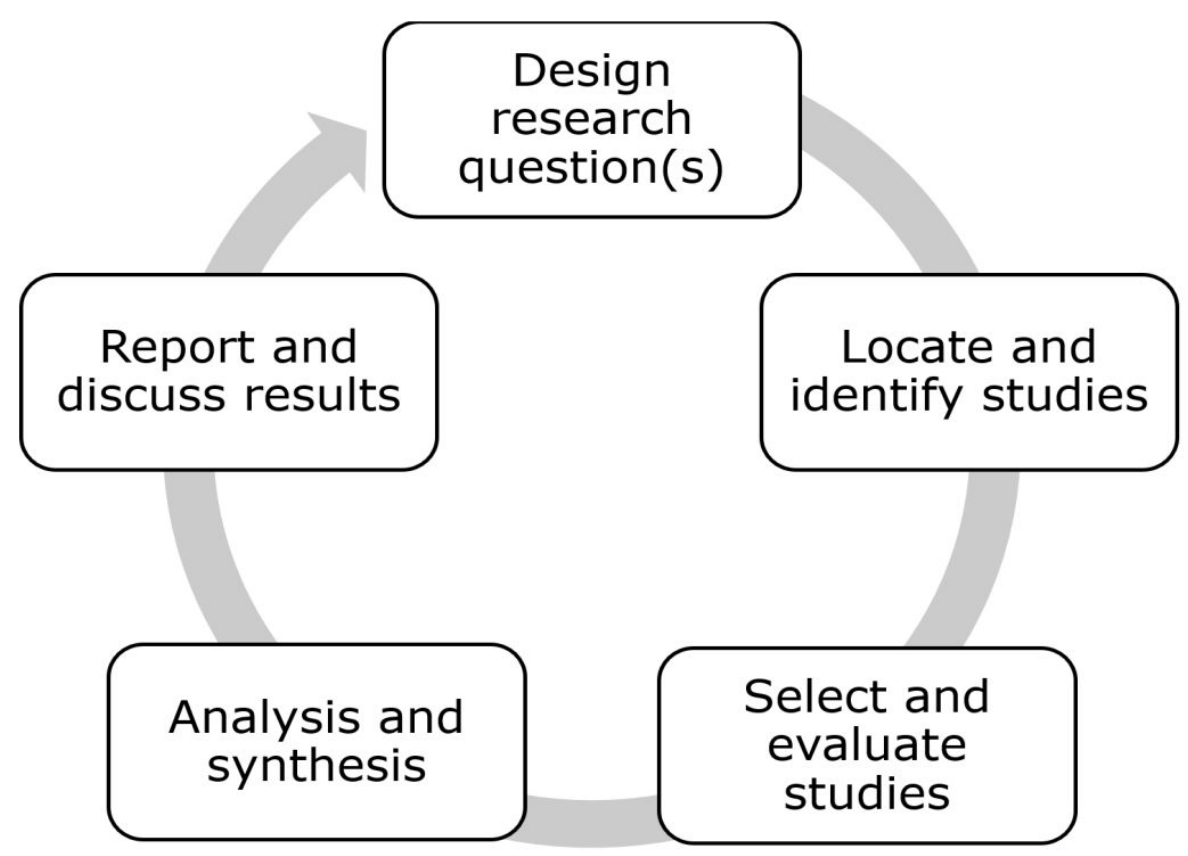

Figure 1: Systematic Review Process Model (Denyer and Tranfield, 2009)

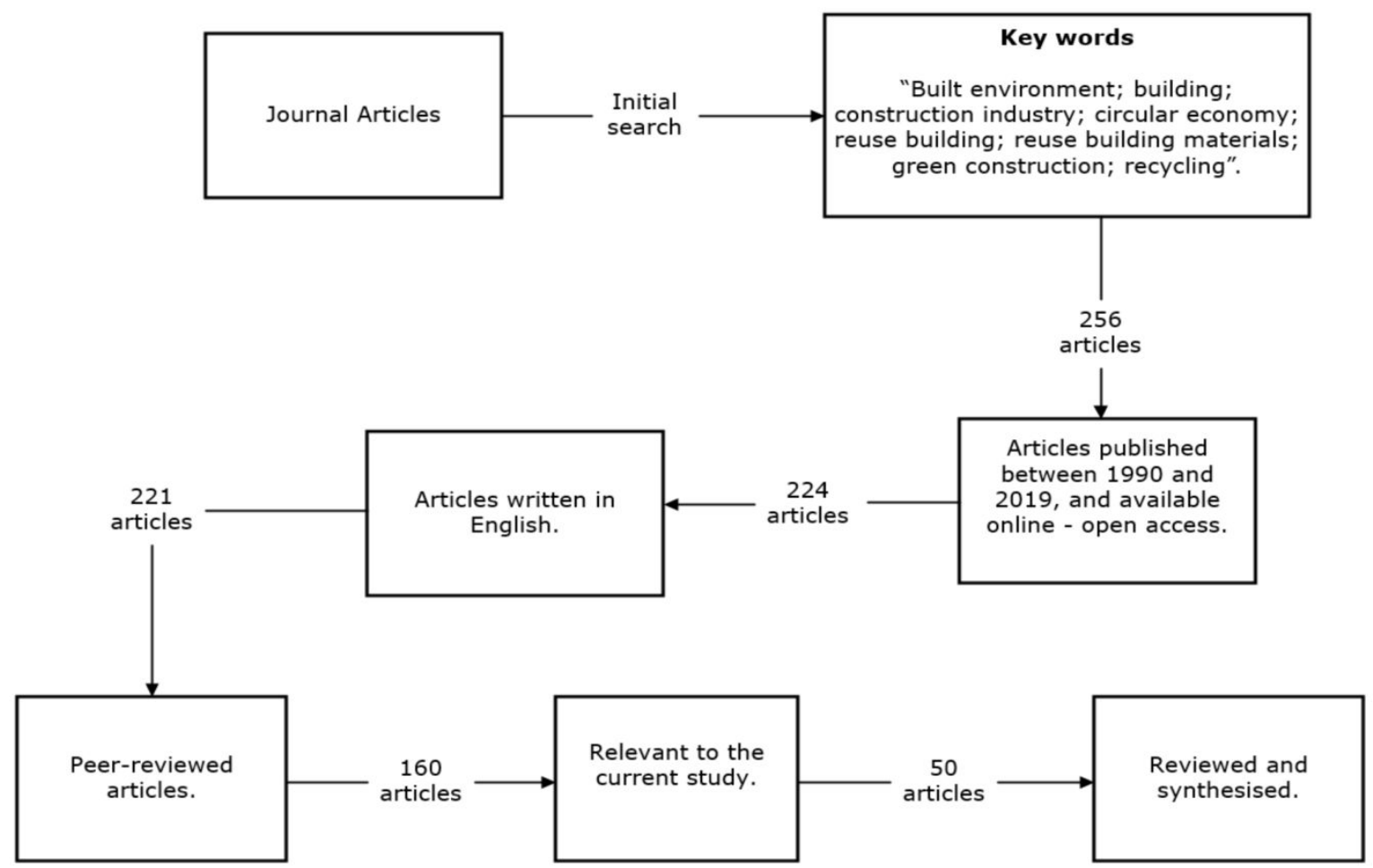

Figure 2: Steps employed for peer-reviewed journal article selection. 




Figure 3: Peer-reviewed journal articles published by year (authors generated).

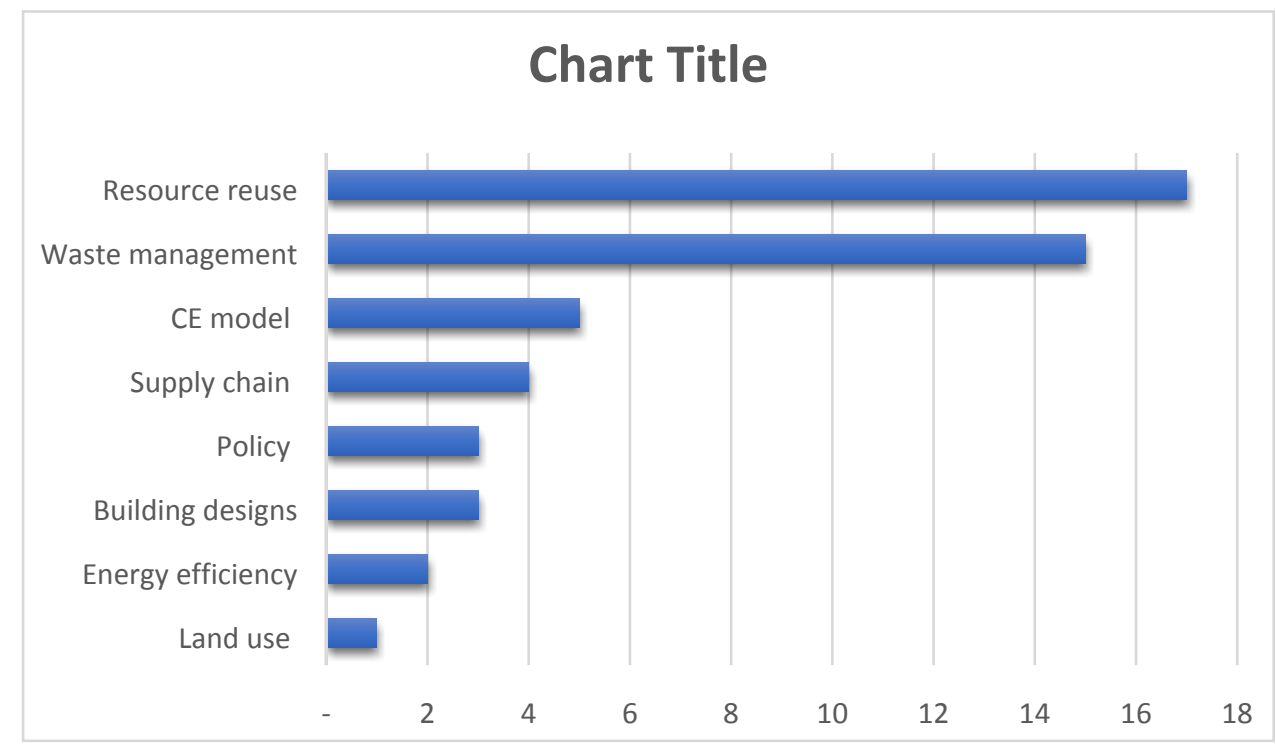

Figure 4: Research concentration (authors generated) 


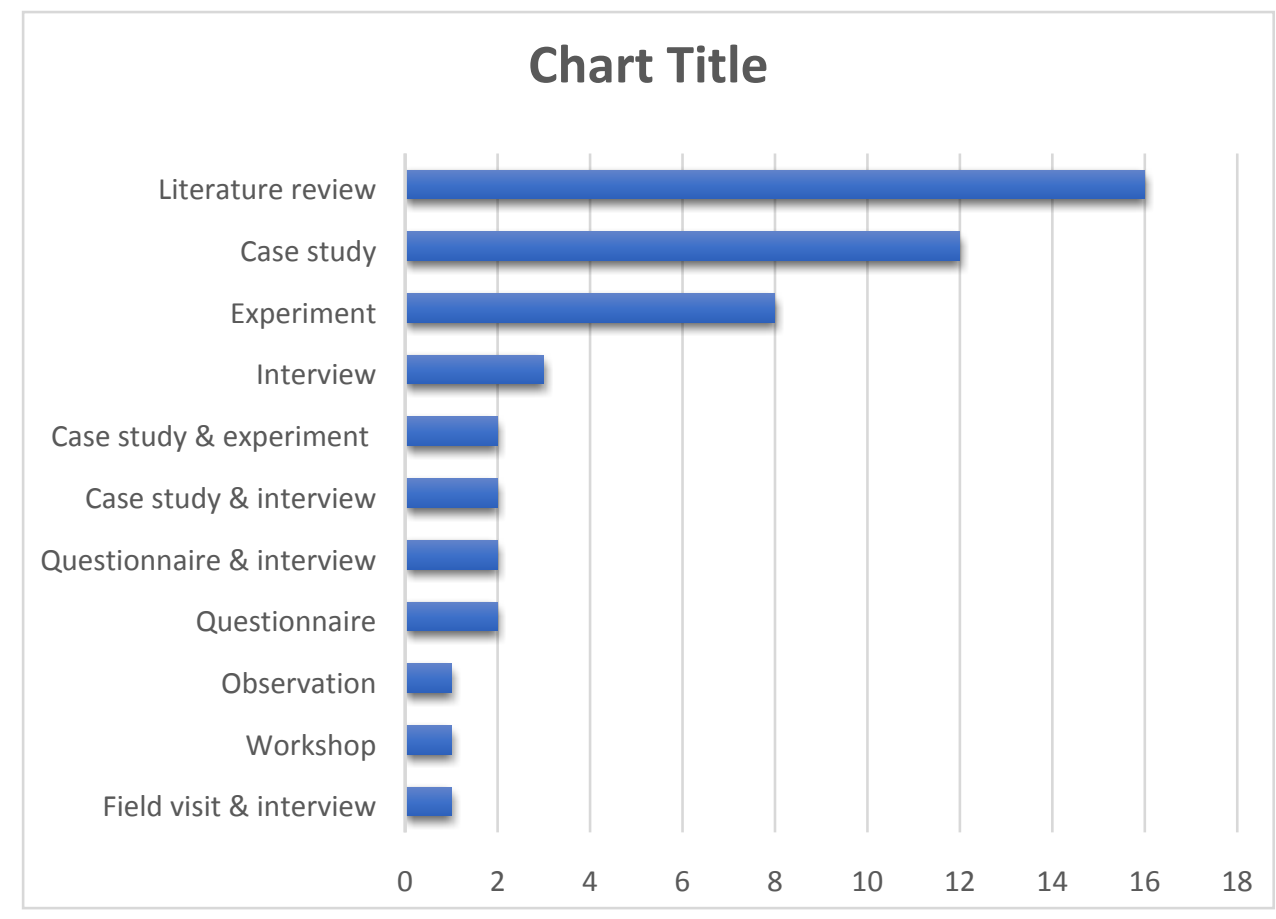

Figure 5: Data collection method

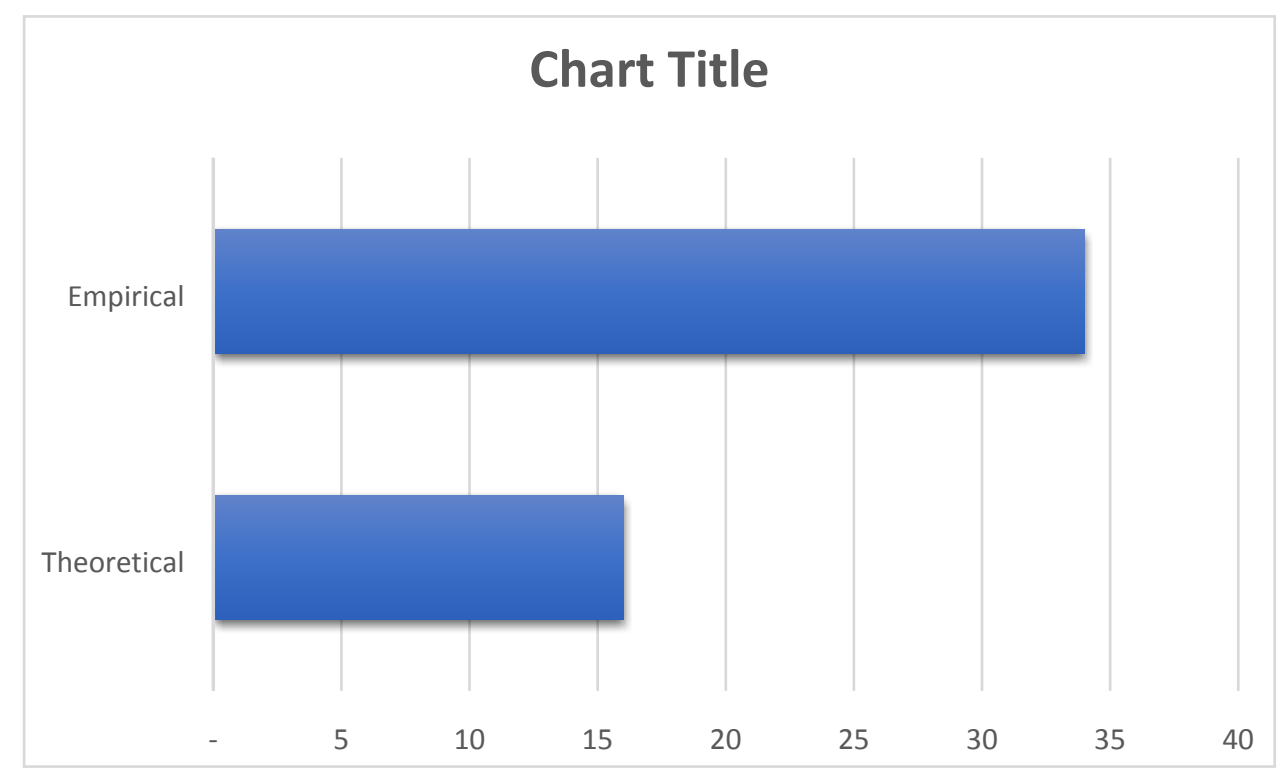

Figure 6: Article classification by research method 


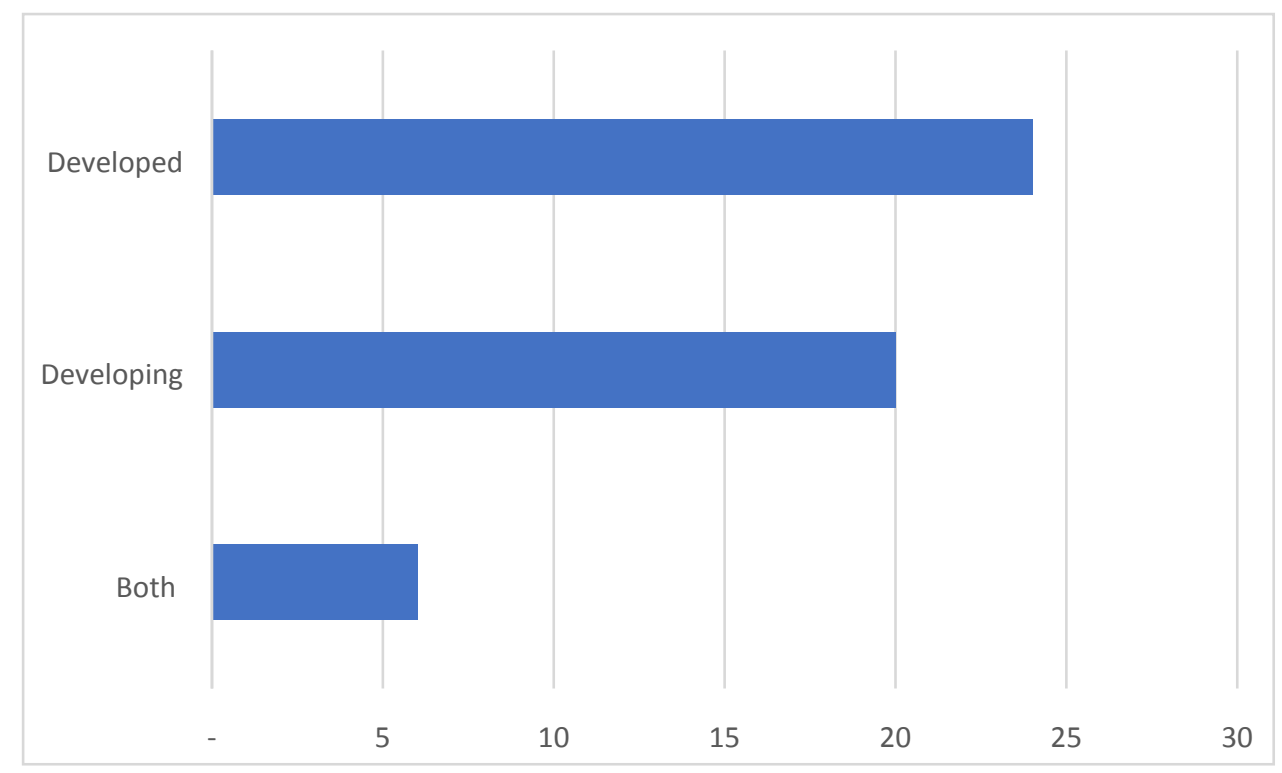

Figure 7: Article segregation by economy

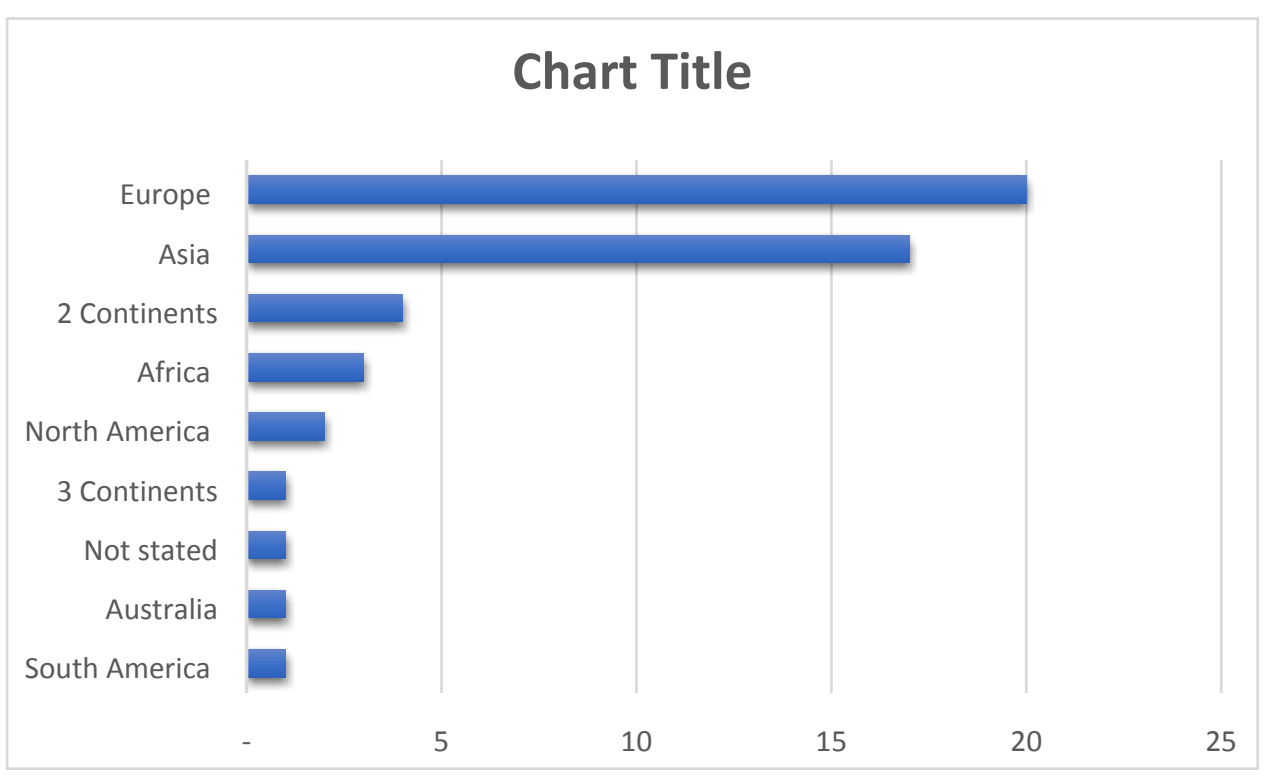

Figure 8: Article segregation by continent 


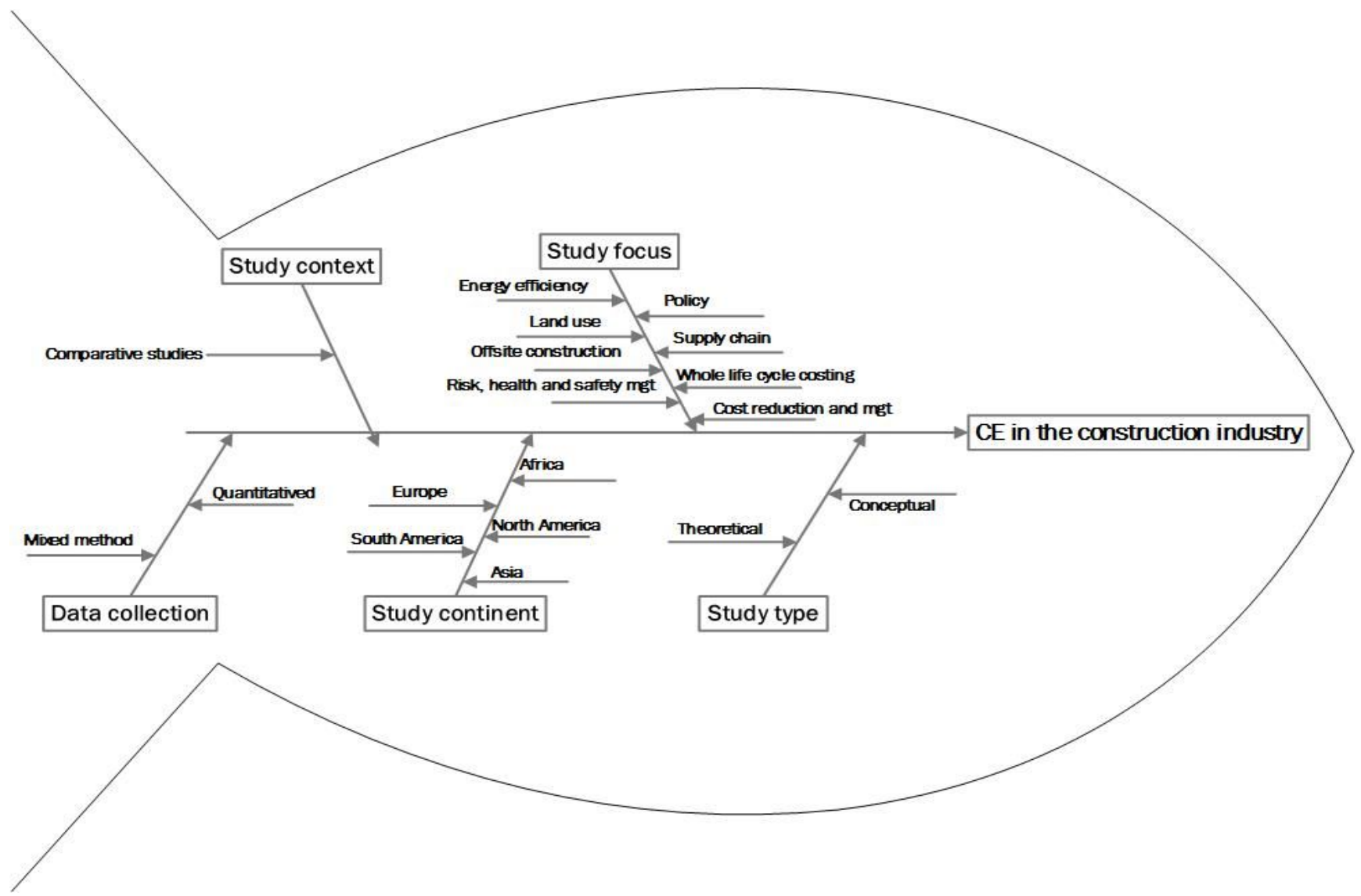

Figure 9: Framework for the future research agenda. 